\title{
An Assessment Methodology for Thermal Energy Storage \\ Evaluation
}

\author{
D. R. Brown \\ J. A. Dirks \\ M. K. Drost \\ G. E. Spanner \\ T. A. Williams
}

November 1987

Prepared for the U.S. Department of Energy under Contract DE-AC06-76RLO 1830

Pacific Northwest Laboratory

Operated for the U.S. Department of Energy

by Battelle Memorial Institute 


\section{DISCLAIMER}

This report was prepared as an account of work sponsored by an agency of the United States Government. Neither the United States Government nor any agency thereof, nor Battelle Memorial Institute, nor any of their employees, makes any warranty, expressed or implied, or assumes any legal liability or responsibility for the accuracy, completeness, or usefulness of any information, apparatus, product, or process disclosed, or represents that its use would not infringe privately owned rights. Reference herein to any specific commercial product, process, or service by trade name, trademark, manufacturer, or othenwise, does not necessarily constitute or imply its endorsement, recommendation, or favoring by the United States Government of any agency thereof, or Battelle Memorial Institute. The views and opinions of authors expressed herein do not necessarly state or reflect those of the United States Government or any agency thereof, or Battelle Memorial Institute.

\section{PACIFIC NORTHWEST LABORATORY operated by \\ BATTELLE MEMORIAL INSTITUTE for the \\ UNITED STATES DEPARTMENT OF ENERGY \\ under Contract DE-AC06-76RLO 1830}

\begin{tabular}{|c|c|}
\hline \multicolumn{2}{|c|}{ Printed in the United States of America } \\
\hline \multicolumn{2}{|c|}{$\begin{array}{l}\text { Available from } \\
\text { National Technical Information Service }\end{array}$} \\
\hline \multicolumn{2}{|c|}{$\begin{array}{l}\text { National Technical Information Service } \\
\text { United States Department of Commerce }\end{array}$} \\
\hline \multicolumn{2}{|c|}{5285 Port Royal Road } \\
\hline \multicolumn{2}{|c|}{ Springfield, Virginia 22161} \\
\hline \multirow{2}{*}{\multicolumn{2}{|c|}{$\begin{array}{l}\text { NTIS Price Codes } \\
\text { Microfiche A01 }\end{array}$}} \\
\hline & \\
\hline \multicolumn{2}{|c|}{ Printed Copy } \\
\hline & Price \\
\hline Pages & \\
\hline 001-025 & A02 \\
\hline $026-050$ & $\mathrm{~A} 03$ \\
\hline 051-075 & A04 \\
\hline $076-100$ & A05 \\
\hline $101-125$ & A06 \\
\hline $126-150$ & $\mathrm{~A} 07$ \\
\hline $151 \cdot 175$ & $\mathrm{~A} 08$ \\
\hline $176-200$ & A09 \\
\hline $201-225$ & A010 \\
\hline $226-250$ & A011 \\
\hline $251-275$ & A012 \\
\hline $276-300$ & A013 \\
\hline
\end{tabular}



D. R. Brown
J. A. Dirks
M. K. Drost
G. E. Spanner
T. A. Williams

November 1987

Prepared for

the U.S. Department of Energy

under Contract DE-ACO6-76RLO 1830

Pacific Northwest Laboratory

Richland, Washington 99352 


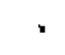


This report documents an assessment methodology for evaluating the cost, performance, and overall economic feasibility of thermal energy storage (TES) concepts. The methodology was developed by Therma] Energy Storage Evaluation Program personnel at Pacific Northwest Laboratory (PNL) for use by PNL and other TES concept evaluators. The methodology is generically applicable to all TES concepts; however, specific analyses may require additional or more detailed definition of the ground rules, assumptions, and analytical approach.

The overall objective of the assessment methodology is to assist in preparing equitable and proper evaluations of TES concepts that will allow developers and end-users to make valid decisions about research and development (R\&D) and implementation. The methodology meets this objective by estab1ishing standard approaches, ground rules, assumptions, and definitions that are analytically correct and can be consistently applied by concept evaluators. 


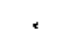




\section{ACKNOWLEDGMENTS}

Several persons at PNL have assisted the authors in preparing this document. The authors would specifically like to thank S.J. Arey, D.J. Coomes, S.N. Craig, and D.L. Stiles for their contributions. 


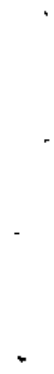




\section{CONTENTS}

SUMMARY

$i i i$

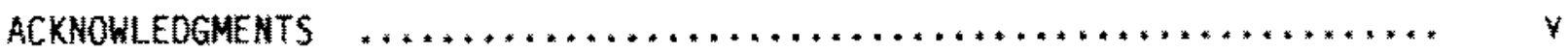

PERFORMANCE NOMENCLATURE $\ldots \ldots \ldots \ldots \ldots \ldots \ldots \ldots \ldots \ldots \ldots \ldots \ldots \ldots \ldots \ldots \ldots$

ECONOMIC NOMENCLATURE $\ldots \ldots \ldots \ldots \ldots \ldots \ldots \ldots \ldots \ldots \ldots \ldots \ldots \ldots \ldots \ldots \ldots \ldots \ldots \ldots \ldots \ldots \ldots \ldots$

1.0 INTRODUCTION $\ldots \ldots \ldots \ldots \ldots \ldots \ldots \ldots \ldots \ldots \ldots \ldots \ldots \ldots \ldots \ldots \ldots \ldots \ldots \ldots \ldots$

2.D TEAM: THE ECONOMIC ANALYSIS MODEL $\ldots \ldots \ldots \ldots \ldots \ldots \ldots \ldots \ldots \ldots \ldots \ldots \ldots$

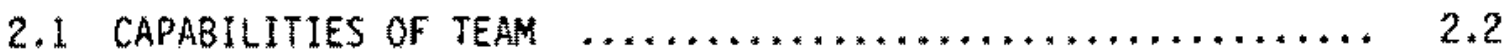

2.1 .1 Project Cash Flow Calculations $\ldots \ldots \ldots \ldots \ldots \ldots \ldots \ldots 2.2$

2.1 .2 Project Economic Analysis $\ldots \ldots \ldots \ldots \ldots \ldots \ldots \ldots \ldots$

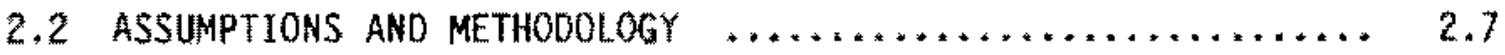

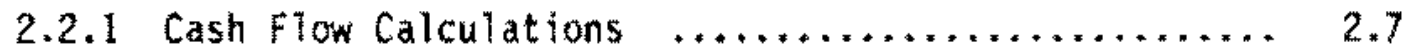

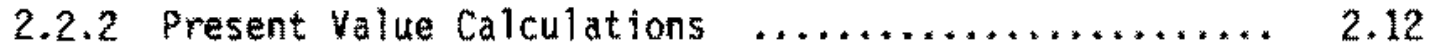

2.2 .3 Figuremof-Merit Calculations $\ldots \ldots \ldots \ldots \ldots \ldots \ldots \ldots \ldots$

3.0 FINANCIAL ASSUMPTIONS $\ldots \ldots \ldots \ldots \ldots \ldots \ldots \ldots \ldots \ldots \ldots \ldots \ldots \ldots * \ldots * * * \ldots .1$

3.1 TAXES $\ldots \ldots \ldots \ldots \ldots \ldots \ldots \ldots \ldots \ldots \ldots \ldots \ldots \ldots \ldots \ldots \ldots \ldots \ldots \ldots \ldots \ldots \ldots+3.1$

3.1 .1 Federal Incone Tax $\ldots \ldots \ldots \ldots \ldots \ldots \ldots \ldots \ldots \ldots \ldots \ldots \ldots \ldots$

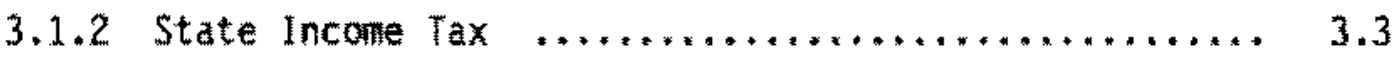

3.1 .3 Property Taxes $\ldots \ldots \ldots \ldots \ldots \ldots \ldots \ldots \ldots \ldots \ldots \ldots \ldots \ldots \ldots \ldots$

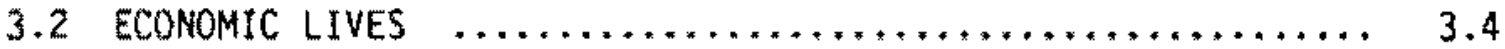

3.2 .1 Industrial Installation $\ldots \ldots \ldots \ldots \ldots \ldots \ldots \ldots \ldots \ldots, 3.5$

3.2 .2 Commercial, Residential, or Municipal

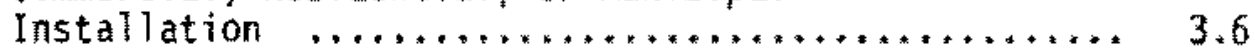

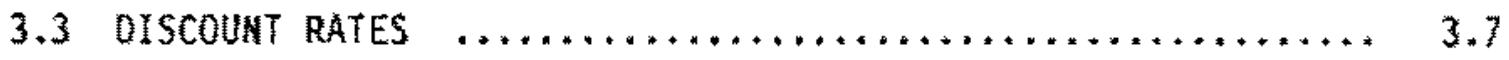

3.3.1 Generic Discount Rate for Industrial and Commercial Investments 
3.3.2 Oiscount Rates for Municipal and Residential Inves tments

3.3.3 Discount Rates for Individual Cash Flow Streams .... 3.12

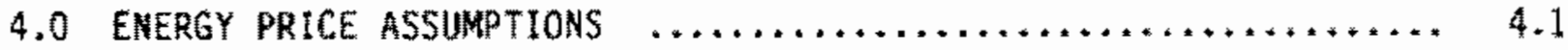

4.1 HYOROCARBON FUEL PRICES $\ldots \ldots \ldots \ldots \ldots \ldots \ldots \ldots \ldots \ldots \ldots \ldots \ldots, 4,1$

4.2 ELECTRICITY PRICES $\ldots \ldots \ldots \ldots \ldots \ldots \ldots \ldots \ldots \ldots \ldots \ldots \ldots, 4.1$

4.3 ERERGY PRICE ESCALATION RATES $\ldots \ldots \ldots \ldots \ldots \ldots \ldots \ldots \ldots, 4.6$

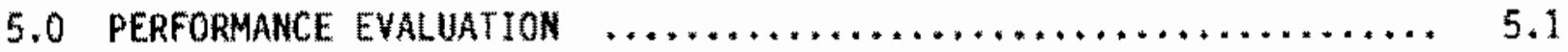

5.1 GENERIC THERMAL ENERGY STORAGE UNIT $\ldots \ldots \ldots \ldots \ldots \ldots \ldots, 5.1$

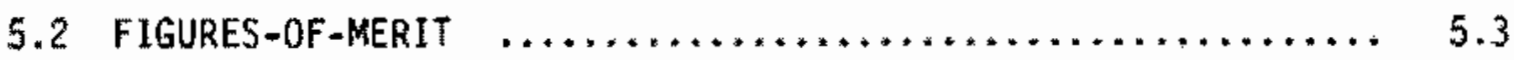

5.3 EVALUATION OF HEAT, WORK, AND AVAILABILITY TERMS $\ldots \ldots \ldots \ldots .5 .5$

5.3.1 Evaluation of Thermal Energy and Avallability from

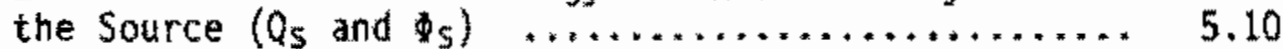

5.3.2 Evaluation of Thermal Energy and Availability Supplied to Storage $\left(Q_{m c}\right.$ and $\left.\Phi_{m c}\right) \ldots \ldots \ldots \ldots \ldots \ldots . \ldots .11$

5.3.3 Evaluation of Thermal Energy and Availability Delivered From Storage (Qnd and $\left.\Phi_{m d}\right) \ldots \ldots \ldots \ldots \ldots 5,14$

5.3.4 Evaluation of Thermal Energy and Availabllity Supplied to the Load $\left(Q_{\ell}\right.$ and $\left.\Phi_{Q}\right) \ldots \ldots \ldots \ldots \ldots \ldots . . . . .65$

5.3 .5 Evaluation of Work Inputs $\ldots \ldots \ldots \ldots \ldots \ldots \ldots \ldots \ldots+\ldots \ldots \ldots$

5.4 APPLICATION OF FIGURES-OF-MERIT TO AQUIFER THERMAL

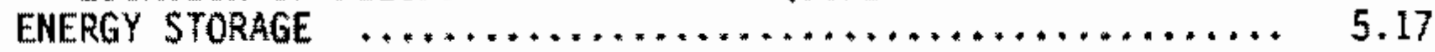

5.4 .1 Charge Efficiency $\ldots \ldots \ldots \ldots \ldots \ldots \ldots \ldots \ldots, 5.17$

5.4 .2 Standby Efficiency $\ldots \ldots \ldots \ldots \ldots \ldots \ldots \ldots \ldots \ldots ., 5.20$

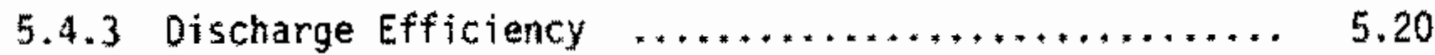

5.4 .4 "Round Trip" Efficiency .................... 5.21

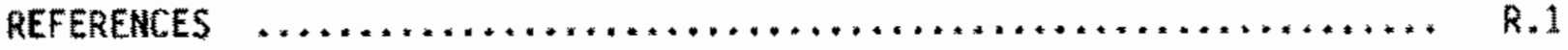

APPENDIX A - GLOSSARY OF ECONOMIC ANO PERFORMANCE TERMS $\ldots \ldots \ldots \ldots \ldots$ A.1

APPENDIX B - AN INTRODUCTION TO ECONOMIC PRINCIPLES ............. B.I 
APPENDIX $C$ - THE DEDUCTIBILITY OF INTEREST OURING CONSTRUCTION $\ldots \ldots \ldots \ldots \ldots \ldots \ldots \ldots \ldots \ldots \ldots \ldots \ldots, c .1$

APPENDIX 0 - MULTIPLE DISCOUNT RATE ANALYSIS $\ldots \ldots \ldots \ldots \ldots \ldots \ldots, 0.1$

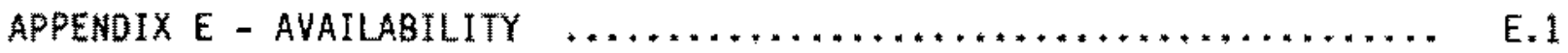




\section{FIGURES}

5.1. Generic Thermal Energy Storage Unit $\ldots \ldots \ldots \ldots \ldots \ldots \ldots \ldots, 5.2$

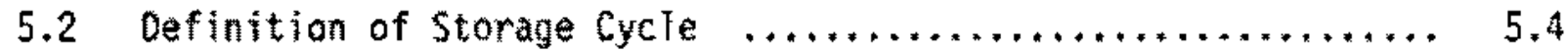

5.3 Generic Thermal Storage Systen Arrangements $\ldots . . . \ldots \ldots \ldots .5 .9$

5.4 Typical Aquifer Thermal Energy Storage Systen $\ldots \ldots \ldots \ldots \ldots .5 .18$

\section{TABLES}

1.1 TES Evaluation Issues $\ldots \ldots \ldots \ldots \ldots \ldots \ldots \ldots \ldots \ldots \ldots \ldots \ldots, 1.2$

2.1 TEAM Assumptions $\ldots \ldots \ldots \ldots \ldots \ldots \ldots \ldots \ldots \ldots \ldots \ldots \ldots, 2.8$

3.1 Modified ACRS Class Life as Determined by ADR Class Life ...... 3.2

3.2 Modified ACRS Depreciation Tables for 1987 and Beyond ........ 3.3

3.3 ADR Class Lives for Equipment and Their Estimated Lives ...... 3.6

3.4 Total Stockholders Equity to Total Debt, 1 st Quarter $1984, \ldots . .3 .9$

4,1 Price of Energy by Source and End-Use Sectors, Base Case $(1986$ Dollars) $\ldots \ldots \ldots \ldots \ldots \ldots \ldots \ldots \ldots \ldots \ldots \ldots \ldots, 4.2$

4.2 price of Energy by Source and End-use Sectors, Low World 0i1 Price - High Growth Case (1986 Dollars) ....... 4.3

4.3 Price of Energy by Source and End-Use Sectors, High World oil Price - Low Growth Case (1986 Dollars) $\ldots \ldots \ldots .4 .4$

4.4 Sumary Electricity Rate Data for Residential, Commercial, and Industrial Sectors (1986 Dollars) ......... 4.6

4.5 Annual Escalation Rates for Various Fuels By Sector -1986 to $2000 \ldots \ldots \ldots \ldots \ldots \ldots \ldots \ldots \ldots \ldots \ldots \ldots \ldots, 4.8$

5.1 Figures-of-Merit $, \ldots \ldots \ldots \ldots \ldots \ldots \ldots \ldots \ldots \ldots \ldots, 5.6$

5.2 Losses Included in Efficiencies $\ldots \ldots \ldots \ldots \ldots \ldots \ldots \ldots \ldots .5 .8$ 
PERFORMANCE NOMENCLATURE

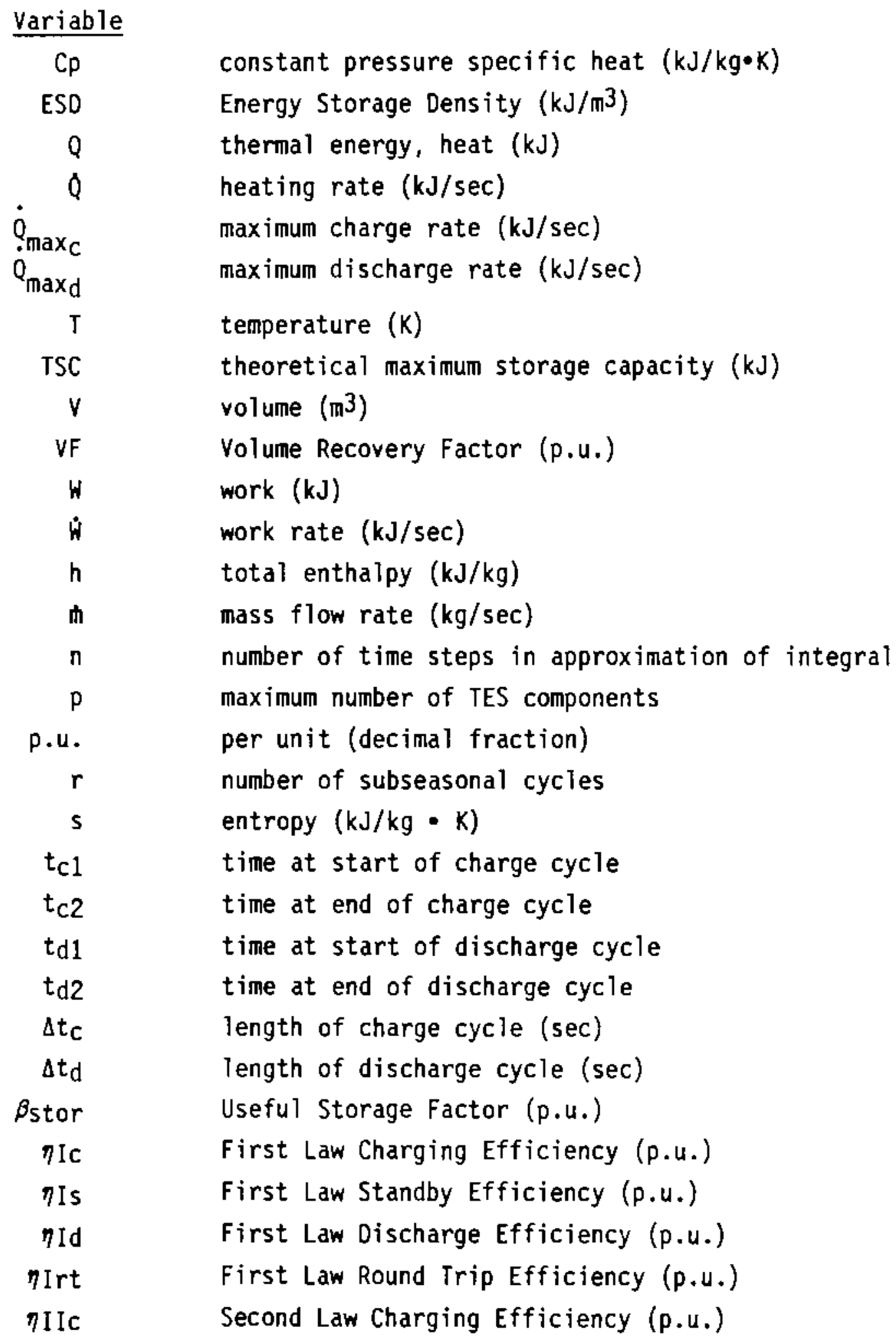

$x i$ 


\begin{tabular}{|c|c|}
\hline ilis & Second Law Standby Efficiency (p.u.) \\
\hline$\eta 11 d$ & Second Law Discharge Efficiency (p.u.) \\
\hline nilrt & Second Law Round Trip Efficiency $\left(p . u_{*}\right)$ \\
\hline$f$ & density $\left(\mathrm{kg} / \mathrm{m}^{3}\right)$ \\
\hline H & internal energy $(\mathrm{kJ} / \mathrm{kg})$ \\
\hline$y$ & specific volume $\left(\mathrm{m}^{3} / \mathrm{kg}\right)$ \\
\hline$\phi$ & specific available energy $(\mathrm{kJ} / \mathrm{kg})$ \\
\hline 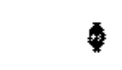 & total available energy (kJ) \\
\hline
\end{tabular}

Subscripts

nct

related to aquifer fluid during charge phase

nech

related to high-temperature aquifer fluid during charging phase?

mal

related to low-temperature aquifer fluid during charging phase

nd

related to aquifer fluid during discharge phase

midh

related to high-temperature aquifer fluid during discharge phase

mde

related to low-temperature aquifer fluid during discharge phase

$\ell$ related to load fluid (user of stored energy)

th

related to high-temperature load fluid (user of stored energy)

ee

related to low-temperature load fluid (user of stored energy)

$s$

related to source fluid (external heat source)

sh

related to high-temperature source fluid (extemal heat source)

se

related to low-temperature source fluid (external heat source) 
APC

annualized production cost ( $\$ /$ unit of annual output)

ATCF

after tax cash flow (\$)

CIn initial capital investment for one of eight cost categories, measured as "overnight" costs, i.e., costs excluding interest and escalation during construction (\$)

CIT total initial capital investment, the sum of all CIn (\$) the correlation of the changes in the cash flow stream $x$ and the return on the market portfolio (no units) the covariance of the changes in the cash flow steam $x$ and the return on the market portfolio (no units) capital recovery factor (p.u.) construction time (years) market value of the company's outstanding debt (\$) the debt fraction, the ratio of debt to debt plus equity (p.u.)

Dn total investment for one of eight initial capital investments or one of ten interim capital investments depreciation factor (p.u.) total depreciation (\$) expected annual rate of return on assets ( $p . u_{.}$) expected annual return on corporate bonds (p.u.) expected annual return on the market portfolio (p.u.) market value of the company's outstanding equity (\$) the equity fraction, the ratio of equity to debt plus equity (p.u.)

ICIn total interim capital investment (\$)

MBtu income tax payment (\$) plant operating life (years)

NAPC million British thermal units (no units) nominal annualized production cost (\$/unit of annual output) net present value (\$) 
Oann

ogin

PR

PT

RAPC

Rn

RT

SCIn

SCIT

Std (mkt)

$s t d(x)$

T)

II

T\$

itt

$k$

kel

ke

ptf

rf

syf

BAssets

Gebt

BEquity

$\beta_{\mathrm{X}}$ total operation and mantenance expenses (\$)

one of eight annual operation and maintenance

expenses $(\$)$

annual production rate (units/year)

property tax payment (\$)

real annualixed production cost (sunit of annual output)

one of five revenue streams (\$)

total revenue $(\$)$

salvage value for $\mathrm{Cln}(\$)$

total salvage value (\$)

the standard deviation of the return on the market

portfolio $(p . u)$

the standard deviation of the percentage changes in cash

flow strean $x(p . u$,

maximum federal incone tax rate $(p . u$,

taxable income (\$)

ayerage naximum state incone tax rate $(p . u)$

general inflation rate (p.u.)

the year i or the ith year

income tax rate $(p, u$.

overall discount rate (p.u.)

the return on debt

the return on equity

property tax rate (p.u)

risk-free annual rate of return $(p, u)$

salvage value fraction $(p . u)$

a measure of the volatility of a company's debt and equity securities relative to the market (no units)

a measure of the votatility of a company's debt security relative to the market (no units)

a measure of the volatility of a company's equity

securlty relative to the market (no units)

a measure of the market risk of a cash flow stream (no units) 
Subscripts

$\begin{aligned} & \text { dedi deductible as an expense in year } i \\ & 9 \text { escalation rate for cash flow strean } \\ & i \text { a cash flow stream occurring in year } i \\ & k \text { discount rate for a cash flow strean } \\ & p \text { reference price year for a cash flow stream } \\ & \text { py present value of a cash flow stream } \\ & \text { pui present value of a cash flow stream occurring in year i } \\ & \text { put present value of income taxes generated by a cash flow stream }\end{aligned}$





\subsection{INTRODUCTION}

This report documents an assessment methodology for evaluating TES concepts. The purpose of this assessment framework is to facilitate the development of consistent, equitable, and comparable evaluations. The framework consists of an economic methodology and a collection of ground rules, assumptions, and approaches that help define how to characterize TES costs, performance, and overall economic attractiveness. This framework will be used by PNL for technical assessments conducted within the Thermal Energy Storage Evaluation Program and is suggested for use by other contractors conducting TES analyses for the U.S. Department of Energy. This section provides an overview of issues affecting the evaluation of TES concepts. Sections 2.0 through 5.0 provide specific definition of the ground rules, assumptions, approaches and economic methodology to be followed. Additional background and detail are provided in Appendices $A$ through $E$.

The diverse nature of potential TES technologies and applications creates a higher level of complexity for conducting concept evaluations than exists for many other energy technologies. Potential end-users of TES systems encompass residential, commercial, and industrial sectors. Prospective storage temperatures range from below $0^{\circ} \mathrm{C}$ to beyond $1000^{\circ} \mathrm{C}$. The widely varying enduser requirements and multiple types of potential storage media result in a large matrix of potential concepts, often requiring a unique approach to their evaluation. An initial grasp of the potential complexity surrounding TES evaluations can be developed by considering the issues listed in Table 1.1 . Each of the issue groups defined in Table 1.1 is briefly discussed in the paragraphs that follow.

The most common benefit of a TES system is displacing consumption of expensive energy forms with those that are less expensive. This might occur by substituting a different, less expensive energy form (e.g., by recovering, storing, and utilizing "waste heat") or by storing energy when it is inexpensively priced for use when its purchase would be more expensive (e.g., taking advantage of off-peak electricity rates). Other potential benefits are more subtle. Incorporating TES equipment could decrease the size and investment in parts of the energy delivery system or increase the productivity of an 
TABLE 1.1. TES Evaluation issues

Economic Methodology

1. What are the benefits to be derived from TES?

2. What figures-of-merit best illustrate TES systen economics?

3. Will more than one econonic methodology be required or desirable?

\section{Cost and Financing}

1. What assumptions should be used for current and future energy prices?

2. What assumptions should be used for modeling finances?

3. What cost accounts are necessary to ensure consistent definition of costs?

4. What approach should be used for estimating the cost of unique elements?

\section{Application Characteristics}

1. What is the nature of the current technology TES is augmenting or replacing?

2. What are the TES system boundaries?

3. What are the characteristics of the TES energy source?

4. What is the "typical" size of the many potential TES applications?

\section{Performance}

1. What techniques should be used for calculating system performance?

2. What should the reference anbient conditions be?

3. How should performance be measured and reported?

\section{Other}

1. How should differential environmental and safety issues be addressed?

2. How should TES systems for different applications be compared?

entire process. A TES system could also potentially impact the quality of the process' product. The nature of these multiple benefits dictates that several economic figures-of-merit and economic models need to be employed. A net present value approach (NPV) is appropriate for evaluating energy substitution impacts, but a production cost model is required for evaluating impacts on process economics. For example, suppose TES equipment could be implemented to recover waste heat from a batch-fired (periodic) kiln in a brick factory. 
If the only benefit is a reduction in energy costs, then the evaluation would focus on calculating the NPV of investing in the TES equipment. In general, an investment with a positive NPV would be accepted, while an investment with a negative NPV would not. If the new TES equipment also reduces the kiln cycle time, then the production economics of the entire brick manufacturing process would have to be considered. A reduction in the total cost of producing bricks would favor implementation of the TES equipment. The economic model described in Section 2.0 will handle either of these situations and will calculate the NPV of an investment in TES equipment, the levelized process production cost, and other economic figures-of-merit.

Energy prices and financial assumptions typically have a big impact on technology comparisons and are often the subject of sensitivity analyses. Appropriate financial assumptions (discount rates, tax rates, tax credits, depreciation, economic lifetimes, etc.) are presented in Section 3.0, while current and future energy price assumptions are documented in Section 4.0.

Operation and maintenance (0\&M) and capital cost account structures help evaluators standardize the estimating process by providing a list of cost elements to include (or at least consider) in the estimate and a format for consistently reporting the costs of individual elements. In general, storage system capital costs can be grouped into the following four elements: storage media, media containment, charging equipment, and discharging equipment. The diverse nature of TES technology makes it difficult to define a more detailed accounting structure that would be generally applicable. Estimating the cost of most TES elements should not present any special difficulties because the elements are typically similar to standard equipment already commercially available on an individual basis (e.g., pipes, pumps, heat exchangers, tanks, etc.). Estimating the cost of unique elements will require special approaches that depend on their specific characteristics.

Defining application characteristics is a critical part of the evaluation process. The nature of the current technology that TES is replacing or augmenting could greatly influence TES feasibility. The system boundary for the evaluation may focus on the TES system or may need to include the entire production facility, depending on the impact of the TES system (see discussion of 
multiple benefits above). Characterizing the energy source is necessary for designing the TES charging equipment. Finally, the potential for economiesof-scale make the selection of TES system capacity an important factor. Unfortunately, each of these important issues can only be defined in the context of a specific system, and so are not addressed in this generic assessments methodology.

Performance issues also include specific issues that are technology or application specific. The specific method for calculating performance will largely be unique for a technology/application group. Ambient conditions may also differ from one application to another. Figures-of-merit and reporting procedures are less specific to a technology and application, however. Section 5.0 defines performance figures-of-merit that will be used by PNL for technical assessments.

Still other potential issues are difficult to treat in a generic methodology of this type, but will likely need to be considered in certain circumstances. Any differential environmental and safety impacts associated with a TES system must be identified. In general, the impact of these factors cannot be easily measured in economic terms as can cost and perfomance. A separate qualitative (or quantitative in non-dollar terms) assessment of these factors is usually warranted.

Finally, the comparison of merits for TES systems in different applications will require additional information beyond characterizing cost, performance, and system econonics. The unique requirements of individual applications renders comparisons of cost and performance across these applications meaningless. Other factors such as potential market size and development hurdles will also need to be considered.

The sections that follow define the ground rules, assumptions, approaches, and models to be used for evaluating TES systems. The economic model is described in Section 2.0. Sections 3.0 and 4.0 specify financial and energy price assumptions, respectively. Perfomance figures of-merit are presented in Section 5.0. The appendices include additional background information and details regarding specific issues. A glossary of economic and perfomance terms are defined in Appendix A. Append $1 \times$ B discusses some basic principles of 
economic evaluations. Appendix $C$ describes the impact of changes in the deductibility of interest during construction set forth by the 1986 Tax Reform Act. The theory and impact of multiple discount rates are presented in Appendix 0. Finally, Appendix E provides a definition for the concept of "availability," 


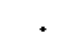




\subsection{TEAM: THE ECONOMIC ANALYSIS MODEL}

The final evaluation of TES technologies (or any technology) will eventually be made in the marketplace, as industry and other users of TES systems consider the economic merits of the technology. For TES systems to be acceptable to a user they must have projected economic benefits greater than their projected costs.

The Economic Analysis Model (TEAM) is a financial analysis model that evaluates the economic feasibility of themal energy storage systems. TEAM generates projections of the cash flows associated with constructing and oper ating a TES system and calculates a variety of economic "figures-of-merit" to help determine the econonic feasibility of the TES system. TEAM can perform detailed financial evaluations of projects for well-specified designs, but is flexible cnough to also allow easy use for prelininary evaluations of projects with only conceptual cost and performance data. TEAM can quickly perform sensitivity analyses on the key project uncertainties feither performance or cost) to address the impact of these parameters on project economics.

Using TEAM requires the input of general project information (such as process annual production rate), general economic assumptions (such as inflation rates), and estimates of project revenues and costs. Output from TEAM for the project includes:

- annual cash flows for capital, operations and maintenance (oxM), taxes, and revenues for each year

- net present value

- internal rate of return

- payback period

- discounted payback period

* laveltzed, life-cycle production cost in both nominal and real terms, (a)

(a) The economic terms listed here and others are defined in Appendix $A$ and discussed in Appendix B. 


\subsection{CAPABILITIES OF TEAM}

The purpose of TEAM is to calculate the annual cash flows for a thermal energy storage project, and then use the cash flow data to analyze the projest's economic worth. The calculation of cash flows and analys is of project economics are discussed separately below.

\subsubsection{Project Cash Flow Calculations}

TEAM can individually analyze a wide number of project cash flows includw ing:

- initial capital

* Interir capital

- O\&M

- revenue

- saluage

- income and property taxes.

These cash flows can be modeled via user-specified escalation rates, or through explicit entry of yarious cash flows. In the former case, the user specifies cash flows for a single reference year and the model automatically calculates cash flows for future years based on a user-specified anmul escalation rate. In the latter case, the user manually enters each cash flow for each year it occurred. This option would be used for nodeling fluctuating cash flows.

TEAM can analyze investments from total cost approach (all costs and revenues considered), or a differential cost approach (only differential costs and revenues included). A differential cost approach only considers the cash flows associated with a process that have changed because new equipment or procedures have been incorporated. The net present value of investing in a TES systen would normally be calculated via a differential cost approach: while TEAM is specifically taliored for TES applications, to could also be applled to a wide range of analyses.

By using default assumptions, TEAM can quickly analyze TES systems for screening purposes with very little system information required. Where additional information is avallable for example, several categories of capital 
equipment, each with different deprectation schedules). TEAM is able to perform a more detalled analysis of the project economics. Sone of the general capabilities in modeling the project cash flows are described below.

Initial Capital Costs - TEAy will automatically spread capital costs over the construction period. Although most IES systems could likely be installed in one year or less (much less for some residential and comercial systens), up to a 6-year construction period can be specified. Initlal capital costs can be expressed in any year's price level, with the model accounting for escalation during construction. Up to eight different categories of initial captial cost, such as storage media, media containment, heat exchangers, ducting, and blowers can be evaluated by the model.

Interin Capital Costs - Some IES systems will have capital costs that occur during the operating life (rather than the construction period) when equipment must be replaced during the project. Interin capital costs can be expressed in any year's price level, with the model accounting for price escalation between the price year and the year that the replacement occurs. Up to 10 different occurrences of interin capital costs may be specified in the model. For example, four pump replacements, four media replacements, and two fan replacenents (for a total of 10 different occurrences) may occur over a project's lifetime.

Depreciation - Depreciation calculations for TES systems are complicated by the fact that different parts of the systen may have different depreciation lives, and that current tax laws have nonunifom depreciation schedules. TEAM tracks depreciation expenses separately for each category of inital capital cost and interim capital cost. Depreciation is calcum lated for each year of the project's life using current federal tax methods, and allows for up to seven depreciation schedules to be used within a single project. The only user input required in the depreciation calculation is specification of the depreciation life for each capital and interin capital account. 
Operation and Maintenance Costs - Up to eight categories of oaf expenses. such as electricity, fuel, maintenance labor, and maintenance naterials can be entered into TEAM. The user expresses oaM costs in any conventent price year and escalation rates applicable to each cost. TEAM automaticMly calculates the nominal dollar OsM cash flows in each year of the project's operating life. As an altemative to assuming uniform escalation of odH costs, each year's D\&M expense may also be entered explicitly into the model.

Revenues - Up to five different types of revenues can be entered into TEAM. For many TES applications, the "revenue" will actually be energy savings. Fron a production cost perspective, "revenue" could also include sales of the primary process product or byproducts. The model employs user-\$upplied escalation rates and price year estimates to calculate the nominal dollar revenues in each year of the plant's operating lifetime. Revenues that do not escalate uniformly may be entered explicitly, year by year, into the model,

Taxes - TEAM automatically calculates property tax payments and combined federal/state income tax payments for each year of the project.

Salvage - Salvage represents the cost or credit associated with removing the TES zysten after its useful life and selling the parts for scrap or for other uses. The cost of removing the TES equpiment may be more. less, or equal to its scrap value; hence, the salvaging process may repre* sent either a cost or a credit. Salvage occurs in the year following the last year of plant operation. Net salvage values are specified by the user as fractions of the initial capital investnents for each investment category. Salvage values are assumed to escalate at the sane rate as for the initial capital investment that will eventually be salvaged. Interest - Interest charges are implicitly accounted for in TEAH by the use of an after-tax weighted cost of capital. This approach to modeling interest-related cash flows assumes that the debt fraction of the investing organization renajus constant during the iffe of the investment and that interest expenses are deductible in the period incurred. Changes to the 
tax laws brought about by the 1986 Tax Reform Act make this latter assumption invalid in some situations. The new rules governing the deductibility of interest and the additional equations required to model the new situation are documented in Appendix $C$.

Net After-Tax Cash Flow - The net after-tax cash flow (ATCF) for each year of the project is calculated from the other cash flows.

\subsubsection{Project Economic Analys is}

As mentioned in Section 2.0, TEAM calculates several economic figures-ofmerit. These calculations are included because of the varying interests of potential TES system users (for example, industry continues to be interested in project payback period despite the fact that better measures of economic performance exist) and because different figures-of-merit highlight different aspects of a project's economic worth. The various figures-of-merit provided by TEAM are discussed briefly below.

Net Present Value - The net present value (NPV) of the project indicates how much the project will increase (or decrease) the wealth of the owner, after accounting for the time value of money. A project with a positive NPV will increase the wealth of the owner and is economically attractive. TEAM can also use a multi-discount rate approach in calculating the NPV. The multi-discount rate approach allows a proper evaluation of projects where the cash flows differ significantly in terms of risk. For example, in a TES project, the cash flows due to tax savings from depreciation may have little risk associated with them, while the cash flows associated with interim capital replacements may have a higher level of risk because of their greater uncertainty. As an alternative to using multiple discount rates, TEAM can also use a single discount rate in the evaluation of the project NPV.

Profitability Ratio - This is the ratio of a project's NPV to the NPV of the initial capital investment. The profitability ratio can be useful in selecting among projects with different capital investment requirements 
in situations where investment funds are limited. When investnent funds are limited, higher profitability ratios are generally preferred to lower profitability ratios.

Internal Rate of Return - A project's internal rate of return (IRR) is defined as the discount rate for which the present value of the aftertax cash flows is equal to zero. Projects with higher IRR values are generally preferred to projects with lower values of IRR. Use of IRR as an economic decision making criteria must be approached with caution for projects with negative cash flows during the plant's operating life. In addition, when there is more than one change in sign (i.e., going fror negative to positive cash flows) there may be several alternative solutions to the IRR.

Payback Period - The payback period is defined as the length of time required to recover the initial capitat investment. The payback period is not an economically correct evaluation procedure because it ignores the time value of money; nonetheless, many businesses continue to consider payback period in evaluating their projects.

Discounted Payback Period - The discounted payback period is similar to the simple payback period, except that the time value of money is accounted for. The discounted payback period is defined as the length of time for the present value of project revenues to equal the present value of the project's initial capital investment. While the discounted payback period corrects the most damning deficiency of the payback period, it still has the drawback of not considering any cash flows that occur after the payback is reached, and so should only be considered in the context of other econonic figures-of-merit.

Annualized Production Cost - The annualized production cost (APC) is defined as the price per unit of production which, if held constant over the project's lifetime, would produce a present value of revenues equal to the present value of all project expenses. When the APC is used to compare two alternatives, the alternatives must be designed to provide equivalent levels of service for the comparison to be neaningful. The $A P C$ can be expressed elther in real dollar or nominal dollar terms. 


\subsection{ASSUMPTIONS AND METHODOLOGY}

The principal assumptions used in TEAM are outlined in Table 2.1. Key assumptions are those that are intrinsic to the methodology and would be difficult for a user to modify for a special application of the model. All other assumptions could be easily modified by the user if needed. For example, the cash flow equations presented in Section 2.2.1 assume uniform escalation relative to a reference base year. A more complicated cash flow pattern can be modeled by TEAM by entering each individual year's estimated cash flow manually. The analytical methodology used in calculating cash flows, present values, and economic figures-of-merit is discussed in the following sections.

\subsubsection{Cash Flow Calculations}

During the construction period for CIn, one of eight possible initial capital investment categories, the nominal dollar cash flow for year i (assuming uniform construction payout) is:

$$
C \operatorname{CI}_{i}=\frac{C I n}{C T} *\left(1+C \operatorname{In}_{g}\right)\left(i-C \operatorname{In}_{p}\right)
$$

where $\quad \mathrm{CIn}_{j}=$ nominal dollar cost in year $\mathrm{i}$

$$
\text { CIn = total "overnight" cost estimate in year CInp dollars }
$$

$\mathrm{CT}=$ construction time

CIng = escalation rate for CIn

CInp = price year for CIn.

\section{Total Initial Capital_Investment}

Total initial capital investment in year $i\left(\mathrm{CIT}_{i}\right)$ is equal to the summation of all individual initial capital investments in year $i$.

\section{Interim Capital Investment ( $\mathrm{n}$ )}

Interim capital investments are assumed to occur in a single year (rather than being spread out over several years as for plant construction). During 
TABLE 2.1. TEAM Assumptions

KEY ASSUMPTIONS

- All cash flows are expressed in nominal year dollars.

- 11 cash flows are assumed to occur at the end of the year.

- The base year for discounting cash flows is year 0 . All cash flows occurring in year 0 are not discounted (i.e., the present value equals the cash flow), with cash flows occurring in all other years being discounted appropriately.

* An effective combined income tax rate is used to cover both state and federal income taxes.

- The project owner is assumed to have other income that can be shielded by tax losses. This results in negative income tax payments being treated as positive after-tax cash flows.

\section{ASSUMPTIONS THAT CAN BE EASILY MODIFIED BY USER}

- Capjtal costs during construction are assumed to be $5 p 1$ it equally among each of the construction years.

- Interin capttal costs are assumed to take place within a single year.

- Property taxes are constant throughout the life of the plant and are calculated as a fraction of the total nominal dollar cost of the initial project capital investment.

- All revenues and operating expenses will comence in year 1 and continue for the life of the project.

- Where uniform construction payout is not valid, the cash flows can be manually entered (in nominal dollars) in each year. 
the year that an interim capital investment occurs, the nominal dollar cash flow for one of 10 possible interim capital replacements is:

$$
\operatorname{ICIn} n_{j}=(I C I n) *(1+\operatorname{ICIng})^{\left(i-I C I n_{p}\right)}
$$

where $I_{C I} n_{j}=$ nominal dollar cost in year $i$ for an individual interim capital replacement

ICIn = total cost estimate in year ICInp dollars

$\mathrm{ICIn}_{\mathrm{g}}=$ escalation rate for ICIn

$I C I n_{p}=$ price year for ICIn.

Total Interim Capital Investment

Total interim capital investment in year $i\left(I C I T_{j}\right)$ is equal to the summation of all individual interim capital investments in year $i$.

Operations and Maintenance (08M) (n)

$08 M$ costs (including fuel expenses) begin in year 1 and occur throughout the plant's operating lifetime. For each of the eight possible 08M categories, O\&M costs in year $i$ are calculated as:

$$
08 M n_{i}=08 M n *\left(1+08 M n_{g}\right)\left(i-08 M n_{p}\right)
$$

where $08 \mathrm{Mn}_{j}=$ nominal dollar cost in year $i$

$$
\begin{aligned}
0 \& M_{n} & =\text { total cost estimate in year } 08 M_{p} \text { dollars } \\
0 \& M n_{9} & =\text { escalation rate for } 08 M n \\
0 \& M n_{p} & =\text { price year for } 08 M n .
\end{aligned}
$$

\section{Total 08M}

Total 08M in year $i$ (O8MT $i$ ) is equal to the summation of all individual 08M costs in year $i$. 
Revenue $(n)$

Plant revenues begin in year 1 and occur throughout the plant's operating lifetine. For each of the five possible revenue categories, revenues in year $i$ are calculated as:

$$
R n_{1}=R n^{*}\left(1+R n_{g}\right)\left(i-R n_{p}\right)
$$

where $\mathrm{Rn}_{i}$ * nominal dollar revenue in year $i$

$R n=$ revenue estimate in year $R_{p}$ dollars

$R n_{\mathrm{g}}=$ escalation rate for $\mathrm{Rn}$

$R n_{p}=$ price year for $\mathrm{Rn}$.

\section{Total Revenue}

Total revenue in year (RTi) is equal to the sumation of all individual revenues in year i.

Depreciation (n)

For initial capital investments, depreciation is assumed to begin in year 0. For interim capital investments, depreciation is assumed to begin in the year in which the investment takes place. Depreciation for both initial and interim capital investments continues until the end of the plants operating life, or the assets depreciable life, whichever comes first. Depreciation for each of eight possible initial capital investments and 10 possible interim capital investments in year i is calculated as:

$$
\text { Oni }=\text { Dn } \star \mathrm{OPF}_{\mathrm{i}}
$$

where $\mathrm{Dn}_{1}$ is depreciation in year $i$, Dn is total asset cost (sumation of al) nominal dollar cash flows), and opfi is the depreciation factor for yoar $i$ (depends on asset life and depreciation tables). 


\section{Total Depreciation}

Total depreciation in year $i(D T i)$ is equal to the summation of all individual depreciation expenses in year $i$.

Salvage Value

All salvage value occurs in the year following the last year of plant operation. Salvage values are possible for all categories of initial capital investment. The salvage value for each initial capital investment category, CIn, is calculated as:

$$
\operatorname{SCIn}=(C I n) * \operatorname{svf} *\left(1+C I n_{g}\right)\left(L+1-C I n_{p}\right)
$$

where $\mathrm{SCIn}=$ the nominal dollar salvage value for $\mathrm{CIn}$

$$
\begin{aligned}
C I n & =\text { total "overnight" cost estimate in year CIn dollars } \\
\text { svf } & =\text { salvage value fraction } \\
C I n_{g} & =\text { escalation rate for } C I n \\
L & =\text { plant operating } l i f e \\
C I n_{p} & =\text { price year for } C I n .
\end{aligned}
$$

Total Salvage Value

The total salvage value (SCIT) is equal to the summation of all individual salvage values.

Property Tax

Property tax payments begin in year 1 and continue throughout the plant's operating life. Property tax payments are calculated as:

$$
\mathrm{PT}_{i}=\mathrm{CIT} \text { * } \mathrm{ptf}
$$

where $P T_{\mathfrak{i}}=$ property tax payment in year $\mathfrak{i}$

CIT = total capital investment for property tax assessments. This is calculated as the summation of all nominal dollars for all categories of initial capital investment. ptf = property tax fraction rate . 
Taxable Income

Taxable income in year $i\left(T_{i j}\right)$ is calculated as:

$$
T_{i}=R_{i}+S C I T i_{i}-O R_{M} T_{i}-D T_{i}-P T_{i}
$$

where RTi, SCITi, O8MTi, OTi, and PTi were defined on pages 2.9 through 2.11 . Incone Taxes

The income tax payment in year $i\left(I_{i}\right)$ is calculated as:

$$
I T_{i}=\mathrm{TI}_{i} * i t
$$

where $\mathrm{itf}$ is combined state and federal income tax rate, and $\mathrm{II}_{\mathrm{i}}$ is defined in Equation (2.8).

After-Tax Cash Flow

The after-tax cash flow in year $i\left(\mathrm{ATCF}_{j}\right)$ is calculated as:

$$
\text { ATCF }_{i}=\mathrm{HI}_{i}+\mathrm{OT}_{j}-\mathrm{IT} \mathrm{T}_{j}-\mathrm{CIT}_{i}-\mathrm{ICIT}_{j}
$$

where $\mathrm{II}_{j}, \mathrm{DT}_{i}, \mathrm{IT}_{i}, \mathrm{CIT}_{j}$, and $\mathrm{ICIT}_{i}$ were defined on pages 2.7 through 2.12 .

\subsubsection{Present Value (PV) Calculations}

pr of Capital Investment

The present value of a capital investment occurring in year $i$ is calculated as:

$$
\operatorname{cIn}_{p y 1}=\frac{\operatorname{cin} \hat{i}}{(1+\operatorname{con})^{1}}
$$

where CInpvi is the present value of CIni. CInk is the discount rate for capital investment $n_{1}$ and $C_{1 n} j$ is defined in Equation (2.1). 
The total present value for each of eight possible initial capital investment categories ( $C I n_{p v}$ ) is equal to the summation over all $i$ of CInpvi. The PV for all initial capital investments (CITpv) is equal to the summation over all $n$ of CInpv.

PV of Capital Investment-Related Income Tax

The present value of the income taxes generated by initial capital investment cash flows is accounted for by the depreciation streams.

\section{PV of Interim Capital Investment}

The present value of an interim capital investment occurring in year $i$ is calculated as:

$$
\operatorname{ICIn}{ }_{p v i}=\frac{I C I n_{i}}{(1+\operatorname{ICIn})^{j}}
$$

where ICInpvi is the present value of $I C I n_{i}, I C I n_{k}$ is the discount rate for interim capital investment $n$, and ICInj is defined in Equation (2.2).

The total present value for ICIn (ICInpv) is equal to the summation over all $i$ of ICInpvi. The PV for all interim capital investments (ICITpv) is equal to the summation over all $n$ of ICInpv.

PV of Interim Capital Investment-Related Income Tax

The present value of the income taxes generated by interim capital investment cash flows is accounted for by the depreciation streams.

PV of $08 M$

The present value of an O\&M expense occurring in year $i$ is calculated as:

$$
08 M n_{p v i}=\frac{08 M n_{i}}{\left(1+08 M n_{k}\right)^{i}}
$$

where $08 M_{p v i}$ is the present value of $08 M M_{i}, 08 M n_{k}$ is the discount rate for O\&M category $n$, and $08 M m_{j}$ is defined in Equation (2.3). 
The total present value for $08 \mathrm{Mn}(0 \mathrm{gMnpv})$ is equal to the summation over all $i$ of $08 M n_{p y i}$. The PV for a $1108 M$ expenses (08MTpv) is equal to the summation over all $n$ of $08 M_{p y}$.

PV of O8M-Related Income Tax

The present value of the incone taxes generated by $08 \mathrm{Mn}$ (08Mrpvt) is cal. culated as:

$$
\text { O\&Mnprt }=-08 M n p v * \text { itf }
$$

where 08Mnpy was defined above and itf was defined in Equation (2.9).

The negative sign indicates that $08 \mathrm{M}$ expenses represent income tax savings. The PV for all income taxes generated by 08M expenses (08MTprt) is equal to the sumation over all $n$ of $08 \mathrm{Mn}_{\mathrm{n}} \mathrm{t}$.

Py of Revenue

The present value of a revenue occurring in year $i$ is calculated as:

$$
R n_{p y i}=\frac{R n_{i}}{\left(1+R n_{k}\right)^{1}}
$$

where $R n_{p v i}$ is the present value of $R n_{i}, R n_{k}$ is the discount rate for revenue category $n$, and $R_{n}$ is defined in Equation (2.4).

The total present value for $R n$ ( $R n_{p y}$ ) is equal to the summation over all $i$ of Rnpri. The PV for revenues (RTpv) is equal to the sumation over all $n$ of $R n_{p v}$.

\section{Py of Revenue-Related income Tax}

The present value of the income taxes generated by $R n$ (Rnpyt) is calculated as:

$$
\text { Rnput }=+ \text { Rn }_{p y} * i \mathrm{tf}
$$

where $R n_{p y}$ was defined above, and itf was defined in Equation (2.9). 
The positive sign indicates that revenues generate income tax payments. The PV for all income taxes generated by revenues ( $R T p v t$ ) is equal to the summation over al1 n of Rnpvt.

\section{PV of Depreciation}

The present value of depreciation occurring in year $i$ is calculated as:

$$
D n_{p v i}=\frac{D n_{i}}{\left(1+D n_{k}\right)^{i}}
$$

where Dnpvi is the present value of $D n_{i}$, Dnk is the discount rate for depreciation, and Dni is defined in Equation (2.5).

The total present value for $D n\left(D n_{p v}\right)$ is equal to the summation over all $i$ of Dnpvi. The PV for all depreciation (DT $p v$ ) is equal to the summation over all $n$ of $D n_{p v}$.

PV of Depreciation-Related Income Tax

The present value of the income taxes generated by Dn (Dnpvt) is calculated as:

$$
\text { Dnprt }=-D n_{p v} * i t f
$$

where Dnpv was defined above, and itf was defined in Equation (2.9). The negative sign indicates that depreciation expenses generate income tax savings. The PV for all income taxes generated by depreciation (DTpvt) is equal to the summation over all $n$ of Dnpvt.

PV of Salvage Value

The present value of salvage value occurring in year $i$ is calculated as:

$$
\operatorname{SCIT}_{p v i}=\frac{\operatorname{SCIT}_{i}}{\left(1+\operatorname{SCIT}_{k}\right)^{i}}
$$


where SCITpvi is the present value of SCITi, SCITK is the discount rate for salvage value, and SCITi is defined on page 2.11 .

PV of Salvage Value-Related Incone Tax

The present value of the income taxes generated by salvage value (SCITprt) is calculated as:

$$
\text { SCITprt }=+5 C I T_{p y}+\text { itf }
$$

where SCITpy is SCITpri (all salyage occurs in the same year), and itf is defined in Equation (2.9).

The positive sign indicates that salvage value generates income tax payments.

\section{PV of Property Tax}

The present value of property tax occurring in year $i$ (PTpyi) is calculated as:

$$
\mathrm{PT}_{p v i}=\frac{P T_{i}}{\left(1+P T_{k}\right)^{i}}
$$

where PTpvi is the present value of PTi. PTk is the discount rate for property tax value, and $\mathrm{Pr}_{i}$ is defined in Equation (2.7).

The total present value for all property tax payments (PTpy) is equal to the sumation over all $i$ of PTpvi. PV of Property Tax-Related Income Tax

The present walue of the income taxes generated by property taxes (PTput) is calculated as:

$$
P T_{p u t}=-P T_{p v} * \text { itf }
$$

where PTpy was defined above, and itf was defined in Equation (2.9). The negative sign indicates that property tax expenses generate income tax savings. 


\section{PV of Income Taxes}

The present value of all income tax expenses (ITpv) is calculated as:

$$
I T_{p v}=0 \& M T_{p v t}+R T_{p v t}+D T_{p v t}+S C I T_{p v t}+P T_{p v t} \quad[\$]
$$

where 08MTpvt, RTpvt, DTpvt, SCITpvt, and PTpvt were defined on pages 2.14 through 2.16.

PV of After-Tax Cash Flow

The present value of all after-tax cash flows $\left(\operatorname{ATCF}_{p v}\right)$ is calculated as:

$$
\begin{aligned}
A T C F_{p v}= & \left(R T_{p v}+S C I T_{p v}\right)-\left(08 M T_{p v}+P T_{p v}+I T_{p v}\right) \\
& -\left(C I T_{p v}+I C I T_{p v}\right)
\end{aligned}
$$

where RTpv, SCITpv, 0\&MT $p v, P T_{p v}, I T_{p v}, C I T_{p v}$, and ICITpv were defined on pages 2.13 through 2.17 .

\subsubsection{Figure-of-Merit Calculations}

Net Present Value

The net present value (NPV) of the project is equal to ATCF $_{p v}$, described above.

\section{Profitability Ratio}

The profitability ratio is defined as the project's net present value divided by the present value of the initial capital investments; the higher the profitability ratio, the better. The profitability ratio is calculated as:

$$
\text { Profitability Ratio }=\frac{\text { ATCF }_{p v}}{C I T p v} \quad \text { [p.u.] }
$$

where ATCFpv was defined above, and CITpv was defined on page 2.13. 


\section{Internal Rate of Return}

The internal rate of return is equal to the discount rate that would result in a present value of zero for the after-tax cash flows. The internal rate of return is calculated using the Lotus olnR function.

\section{Payback Period}

The payback period is the first year that the cumulative after-tax cash flows for the project are positive.

\section{Discounted Payback Period}

The discounted payback period is the first year that the cumblative present value of the after-tax cash flows for the project are positive. Nominal Annualized Production Cost

The nominal annualized production cost is a constant cost in nominal dollars that, over the lifetime of the project, would result in present value equal to the present value of all project costs. The nominal annulized production cost is calculated as:

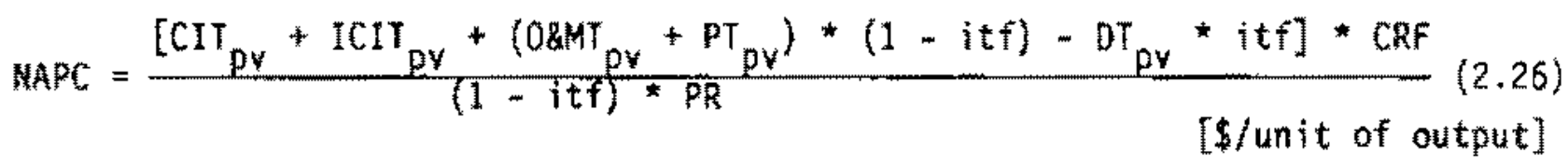

where $\quad$ NAPC $=$ nominal annualized production cost

$$
\text { CITpy = present value of initial capital costs (defined on page 2.13) }
$$$$
\text { ICIT }_{p v}=\text { present value of interim capital costs (defined on page 2.13) }
$$$$
\text { O\&MT }_{p V}=\text { present value of OBM costs (defined on page 2.14) }
$$$$
\text { PTpy = present value of property taxes (defined on page 2.16) }
$$$$
\text { itf = combined state and federal incone tax fraction }
$$$$
\mathrm{DT}_{\mathrm{p} v}=\text { present value of depreciation (defined on page 2.15) }
$$$$
C R F=\text { capital recovery factor (defined below) }
$$$$
P R=\text { annual production rate (assumed constant in each year). }
$$ 
The CRF in the equation for NAPC is calculated as:

$$
C R F=\frac{k}{1-(1+k)^{(-L)}}
$$

where $k$ is the appropriate overall discount rate to use in these types of calculations, and $L$ is the project's operating life.

Real Annualized Production Cost

The real annualized production cost (RAPC) is a constant cost in real dollars that, over the lifetime of the project, would result in a present value equal to the present value of all project costs. The real annualized production cost is calculated as:

$$
\text { RAPC } \left.=\frac{\text { NAPC }}{C R F} * \frac{(k-g)}{(1+g) *\left[1-\left(\frac{(1+g)}{(1+k)}\right)^{L}\right]} \quad \text { [\$/unit of output }\right]
$$

where RAPC is real annualized production cost; $g$ is the general inflation rate; and NAPC, CRF, $k$, and $L$ were defined above. 


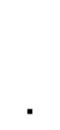




\subsection{FINANCIAL ASSUMPTIONS}

This chapter identifies assumptions for tax rates, tax credits, depreciation, economic lives, and discount rates which should be used for evaluating the economic feasibility of TES technologies. Differences attributable to ownership (industrial, commercial, residential, and municipal) and new construction vis-a-vis retrofit are noted.

\subsection{TAXES}

Three taxes are considered in this analysis. The first two are federal and state income taxes; the third is property tax. Income and property taxes are factors for all users except municipalities.

\subsubsection{Federal Income Tax}

The 1986 Tax Reform Act (TRA) made sweeping changes to federal income tax laws. Major changes were made in marginal tax rates, investment tax credits, and depreciation schedules.

The TRA reduced the maximum marginal tax rate for corporations from $46 \%$ to $34 \%$. This rate applies to taxable income in excess of $\$ 75,000$. For the purposes of this methodology, it is assumed that all industrial and commercial concerns have taxable income in excess of $\$ 75,000$. Thus, under the new law, they will be taxed at the maximum marginal rate of $34 \%$.

The TRA repealed the regular investment tax credit. In addition, the energy investment tax credits are scheduled to be phased-out over the next 2 years. The last allowable year for energy investment tax credits for wind and biomass energy systems is 1987; energy investment tax credits for solar, geothermal, and ocean thermal energy projects are allowable only through 1988. The assessment methodology does not consider regular or energy investment tax credits.

Since 1981, the Accelerated Cost Recovery System (ACRS) has been used to determine the appropriate class life and depreciation schedule. The TRA 
introduced a modified ACRS depreciation system and also increased the number of ACRS class lives. Table 3.1 lists the modified ACRS class lives and corresponding asset depreciation range (ADR) class lives (nidpoint of the ADR range) (Comnerce Clearing House 1987). The ADR class lives were established in 1971 "... to minimize disputes between taxpayers and the Internal Revenue Service as to the useful life of property...." (U.S. Department of the Treasury 1971). The ADR class lives represent estimates of the lives of equipment and other depreciable assets for tax purposes. However, the actual equipment lives tend to be longer than the ADR class lives. (See the discussion below of equipment lives and the table of AOR class lives for various processes.)

The depreciation schedules shown in Table 3.2 assume the midyear convention for depreciation. For the 3,5,7, and 10-year ACRS class life property. the depreciation method is the $200 \%$ declining-balance method with a 5 witch to straight-line depreciation at the time that maximizes the deduction. The depreciation method for 15 and 20 year ACRS class life property is 150 : declining-balance method with a switch to straight-line depreciation at the time that maximizes the deduction.

TABLE 3.1. Modified ACRS Class Life as Determined by ADR Class Life

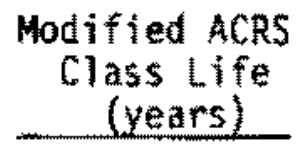

3

5

7

10

15

20
ADR Class

Life

(years)

4 or less

more than 4 but less than 10

10 or more but less than 16

16 or more but less than 20

20 or more but less than 25

25 or more 
TABLE 3.2. Modified ACRS Depreciation Tables for 1987 and Beyond (The yearly applicable percentages for the asset class life)

$\underline{\text { Year }}$

1
2
3
4
5
6
7
8
9
10
11
12
13
14
15
16
17
18
19
20

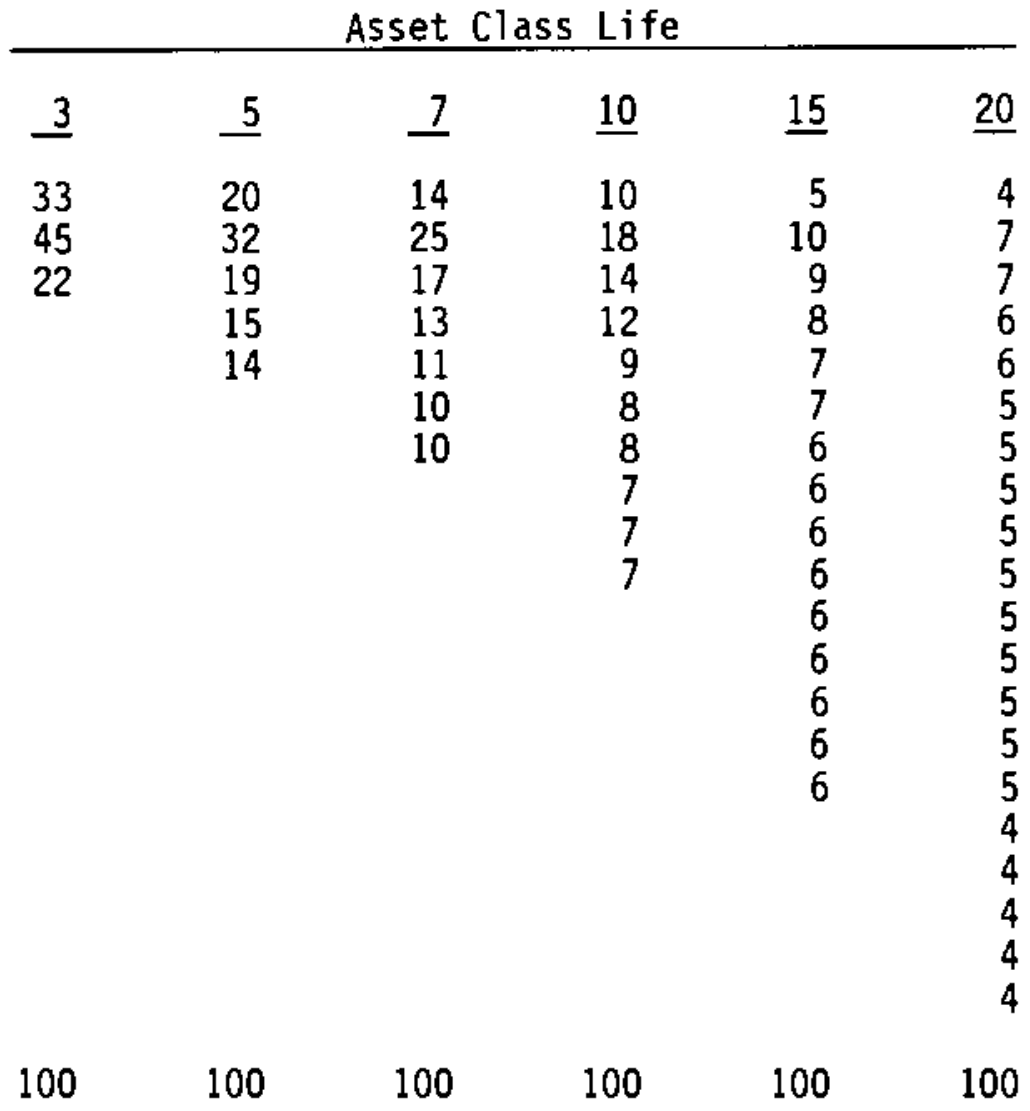

\subsubsection{State Income Tax}

A total of 38 states plus Washington D.C. have state income taxes that are deductible from federal taxes. Six states have no nonbank corporate income taxes, and six states have state income taxes that allow the deduction of federal income tax (Consolidated Capital Communications Group 1985). Because the majority of states have a state income tax and do not allow the deduction of federal income taxes, this type of state income tax will be assumed for the methodology. The average maximum marginal corporate state income tax rate for states of this type is $7.7 \%$. (As with the federal income taxes, it will be assumed that all corporations considering TES have sufficient taxable income to put them in the top bracket.) 
Furthemore, it will be assumed that the allowable deductions from revenue (e.g., depreciation) are the same for state income taxes as they are for federal income taxes (with the exception that state incone taxes will be deductible for federal incone tax purposes). Thus, the state and federal income taxes can be combined into one rate using the following formula:

$$
\text { Combined Rate }=T s+T f(1-T s)=39.1 \quad[p .4 .](3.1)
$$

where Is is the average maximum state income tax rate of $7.7 \%$, and If is the maximum federal incone tax rate of 34 \%.

\subsubsection{Property Taxes}

Under the TRA, property taxes are still deductible from revenue for the calculation of federal incone taxes. Property taxes are highly variable from state to state and within a particular state. These taxes are often set by levies and can be expected to vary over the life of the project. Additionally, many states have personal property taxes that depend on the value of the plant or equipment, which also varies over time. Because property tax rates are so widely variable, the Electric Power Research Institute (EPRI)-recomnended levelized value for property taxes and insurance of $2 \%$ of the installed cost of an investment will be used (EPRI 1982),

\subsection{ECONOMIC LIVES}

Economic life is the length of the economic evaluation period or the number of years cash flows are projected for the economic analysis. Economic lives differ from depreciable lives, but both are related to the ADR class lives defined by tax laws. Economic life is more closely related to the useful life of the facilities being evaluated. The economic 1 ife of the TES device will depend on the useful life of the TES equipment and the life of the process or building into which it is being installed. In general, the economic life will be the lesser of the life of the process or building and the life of the TES equipment. 


\subsubsection{Industrial Installation}

For industrial installations, the economic life of the TES equipment will be assumed to be the lesser of the process equipnent life that is being employed or the estimated TES equipment life. For a retrofit situation, the process equipment life will be assumed to be one-half of the initial process equipment life, if the process equipment is not also undergoing upgrade.

Although much of the equipment in a plant may have actual lives close to their ADR class lives, the more capital and energy-intensive equipment tend to have longer lives. Sone of the equipment with shorter lives (close to their ADR class lives) have planned replacements during the plant life. Conversely, typical estimates of energy-intensive process equipment lives exceed their ADR class lives by a large margin. For example, a glass reverberatory furnace has an estimated 13 fe of 25 years; a textile dryer has an estimated life of 25 years; and a conventional lime kiln has an estimated life of 30 years (Energy and Environmental Analysis, Inc. 1983). These estinates of process equipment lives exceed the ADR class lives for this equipment by 50 to more than $100 \%$, and this equipment represents the energy intensive portions of the industrial processes (where IES equipment is likely to be employed). Thus, as a conservative estimate, the process life, and hence the TES economic life, will be assumed to be 1.5 times the midpoint of the ADR class life of the process equipment (U.S. Department of the Treasury 1971). Table 3.3 provides examples of ADR class lives for equipment and their estimated process or economic lives.

The ADR class life will be used (as required under the TRA) to determine the appropriate depreciation schedule and the estimated process 1 ife will be used for the economic life. The average estimated process life of the equipment in Table 3.3 is 20 years. If a process not listed in the table is being evaluated, and its actual ADR class life cannot be found, this value will be used for the estimated life. The average ADR class life is just over 13 years. The depreciable life for equipment with unknown ADR class Iives will be based on this life. Table 3.1 shows that the modified ACRS 7-year depreciation schedule is appropriate for an ADR class life of 13 years. 
TABLE 3.3. ADR Class Lives for Equipment and Their Estimated Lives

\section{Process}

Petroleum refining

Manufacture of textile mill products:

Knitwear and knit products

Textile mill products (except knitwear)

Finishing and dyeing

Manufacture of paper products:

Pulps

Paper

Manufacture of chemicals and allied products

Manufacture of rubber and plastics:

Rubber products

Finished plastics

Manufacture of leather

Manufacture of stone, clay, glass, and concrete:

Glass products

Cement

Stone and clay products

Manufacture of primary metals:

Ferrous metals

Nonferrous metals

Manufacture of fabricated metal products

Manufacture of machinery:

Metalworking machinery

Electrical equipment

other machines

$\begin{array}{cc}\begin{array}{c}\text { ADR Class } \\ \text { Life, Years }\end{array} & \begin{array}{c}\text { Estimated } \\ \text { Economic } \\ \text { Life, Years }\end{array} \\ 16 & 24 \\ 9 & \\ 14 & 14 \\ 12 & 21 \\ & 18\end{array}$

$16 \quad 24$

$12 \quad 18$

$11 \quad 17$

$14 \quad 21$

$11 \quad 17$

$11 \quad 17$

$14 \quad 21$

$20 \quad 30$

$15 \quad 23$

$18 \quad 27$

$14 \quad 21$

$12 \quad 18$

$12 \quad 18$

$12 \quad 18$

$12 \quad 18$

\subsubsection{Conmercial, Residential, or Municipal Installation}

For a commercial, residential, or municipal installation, the economic life of the TES equipment will be assumed to be the lesser of the building life (50 years) or the estimated TES equipment life. For a retrofit situation, the building life will be assumed to be one-half of the initial life of the building $(50 / 2=25$ years) and the economic life of the TES equipment will be assumed to be the lesser of the building life (25 years) or the estimated TES equipment 1 ife. 


\subsection{DISCOUNT RATES}

To properly account for the time value of money and the riskiness of cash flows, the cash flow streams of a project must be discounted using an appropriate discount rate (k). The proper discount rate to use depends on the market risk of the cash flow stream. In general, the proper discount rate for projects of risk similar to a company's current business is equal to its weighted average cost of capital. This can be calculated using the capital asset pricing model (8realy and Myers 1981):

$$
k=r f+p_{A s s e t s}[E(r m)-r f]=E(r a)
$$

where $\quad k=$ company cost of capital, or hurdle rate for capital budgeting decisions

$E(r a)=$ expected annual rate of return on assets

$r f$ = risk-free annual rate of return

$E(r m)=$ expected annual return on the market portfolio (i.e., all assets).

and

$\beta_{\text {Assets }}=\beta_{\text {Debt }}\left(\frac{\text { Debt }}{\text { Debt }+ \text { Equity }}\right)+\beta_{\text {Equity }}\left(\frac{\text { Equity }}{\text { Debt }+ \text { Equity }}\right)$ [p.u.] (3.3)

where Debt $=$ covariance of return on debt (company specific) with the market return divided by the variance of the market return. Bobt is a measure of the volatility of the individual debt security relative to the market.

Equity = covariance of return on equity (company specific) with the market return divided by the variance of the market return. BEquity is a measure of the volatility of the individual equity security relative to the market.

Debt = market value of the company's outstanding debt Equity = market value of the company's outstanding equity. 
Suggested values for the variables in Equations (3.2) and (3.3) are presented in the following paragraphs.

While the market value of debt and equity are the correct values to use in calculating the beta for assets, these values are highly variable and difficult to obtain. Thus, as a proxy for the market value, the book value of the debt and equity will be used. Table 3.4 lists the equity/debt ratio by standard industrial classification (SIC) code (Consolidated Capital Communications Group 1985); the debt and equity percentage terms of Equation (3.3) are also listed. If the debt and equity betas for a particular industry are known, an asset beta, and hence, a discount rate can be calculated for that industry. If a generic assessment is being made (a particular company or industry is not being considered) then the averages for all the terms should be used.

Because it is difficult to measure investors' expectations, historical values are used as a proxy for the expected return on the market portfolio and the nominal risk-free rate of return. Historical data are also used to calculate an average corporate debt beta (Ibbotson Associates 1987). The annual rates of return (arithmetic mean values) listed below are for the period 1926 through 1986.

- nominal return on government treasury bills $=3.51 \%$

- nominal return on long-term corporate bonds $=5.33 \%$

- nominal return on common stocks $=12.12 \%$.

From the above data, the following values can be surmised:

$\bar{r} f=$ average nominal risk-free rate of return $=3.5 \%$

$E(r m)=$ expected return on the market portfolio $=12.1 \%$

$(\overline{r m-r f})=$ average market risk premium $=8.6 \%$

$E(r c b)=$ expected return on corporate bonds $=5.3 \%$. 
TABLE 3.4. Total Stockholders Equity to Total Debt, 1st Quarter 1984

$\frac{\text { Equity }}{\text { Debt }}=\frac{\text { Total stockholders' equity }}{\text { Short-term loans }+ \text { current installments on L-t debt }+ \text { L-t debt }}$

\begin{tabular}{|c|c|c|c|c|}
\hline \multirow{2}{*}{ SIC Code } & \multirow[b]{2}{*}{ Title } & \multirow{2}{*}{$\frac{\text { Equity }}{\text { Debt }}$} & \multirow{2}{*}{$\frac{\text { Debt }}{\text { Equity }+ \text { Debt }}$} & \multirow{2}{*}{$\frac{\text { Equity }}{\text { Equity }+ \text { Debt }}$} \\
\hline & & & & \\
\hline 20 & Food and kindred products & 1.80 & 0.357 & 0.643 \\
\hline 21 & Tobacco & 2.14 & 0.318 & 0.682 \\
\hline 22 & Textile & 1.96 & 0.338 & 0.662 \\
\hline 26 & Paper and allied products & 1.76 & 0.362 & 0.638 \\
\hline 27 & Printing and publishing & 2.07 & 0.326 & 0.674 \\
\hline 28 & Chemical & 2.23 & 0.310 & 0.690 \\
\hline 281 & Industrial inorganics & 2.01 & 0.332 & 0.668 \\
\hline 283 & Drugs & 3.06 & 0.246 & 0.754 \\
\hline 29 & Petroleum refining & 2.39 & 0.295 & 0.705 \\
\hline 30 & Rubber and plastics & 2.24 & 0.309 & 0.691 \\
\hline 32 & Stone, clay, and glass & 1.77 & 0.361 & 0.639 \\
\hline 33 & Primary metals & 1.15 & 0.465 & 0.535 \\
\hline 3312 & Blast furnaces and steel mills & 0.99 & 0.503 & 0.497 \\
\hline 3356 & Rolling, drawing, extruding & 1.44 & 0.410 & 0.590 \\
\hline 34 & Fabricated metal & 1.86 & 0.350 & 0.650 \\
\hline 35 & Machinery & 2.86 & 0.259 & 0.741 \\
\hline 36 & Electrical machinery & 2.9 & 0.256 & 0.744 \\
\hline 37 & Transportation & 3.14 & 0.242 & 0.758 \\
\hline 371 & Motor vehicles & 4.21 & 0.192 & 0.808 \\
\hline 377 & Aircraft & 3.58 & 0.218 & 0.782 \\
\hline 38 & Instrumentation & 4.79 & 0.173 & 0.827 \\
\hline & $\begin{array}{l}\text { Other durable } \\
\text { manufacturing industries }\end{array}$ & 1.49 & 0.402 & 0.598 \\
\hline Ave & & 2.36 & 0.32 & 0.68 \\
\hline
\end{tabular}


The average beta for corporate bonds (BDebt) can be calculated from these values and the equation shown below:

$$
\begin{aligned}
E(r c b) & =\vec{r} f+\left(\beta_{\text {Debt }}\right)(\overline{r m}-r f) \\
0.053 & =0.035+\left(\rho_{\text {Debt }}\right)(0.086) \\
\beta_{\text {Debt }} & =0.21
\end{aligned}
$$

\subsubsection{Generic Discount Rate for Industrial and Commercial Investments}

To calculate a generic discount rate (i.e., the appropriate discount rate to use when a particular company or industry is not being considered), an asset beta must first be calculated using Equation (3.3). The equity beta used in the generic calculation is the average beta for the market ( 1 by definition), and the average beta for corporate bonds is used for the debt beta. With the calculated asset beta and the other input values identified above, Equation (3.2) is used to compute the generic industrial and commercial discount rate. Thus, the generic discount rate for industrial and comnercial investments is calculated as follows:

$$
\beta_{\text {Assets }}=(0.21) *(0.32)+(1.0) *(0.68)=0.747 \quad[0.4 .](3.5)
$$

and

$$
k=3.5 \%+0.747 * 8.6 \%=9.9 \%
$$

An equivalent approach to calculating the weighted average cost of capital is to explicitly consider the average debt and equity fractions and the average returns on debt and equity. Equation (3.7) defines this relationship.

$$
k=\text { Debtf *E(rcb) }+ \text { Equityf *E(m) [p.u.] }
$$

where

$$
\begin{aligned}
k & =\text { the weighted average cost of capital } \\
\text { Debt } f & =\text { the debt fraction or Debt/(0ebt + Equity) } \\
\text { Equityf } & =\text { the equity fraction or Equity/(Debt + Equity) } \\
E(r c b) & =\text { defined above } \\
E(m) & =\text { defined above. }
\end{aligned}
$$


Substituting the values defined for these variables in Table 3.4 and on page 3.8 yields a value for $k$ identical to that calculated by the capital asset pricing model approach.

$$
\begin{aligned}
k & =(0.32) *(0.053)+(0.68) *(0.121) \quad[p .4 .](3.8) \\
& =9.96 .
\end{aligned}
$$

The after-tax weighted cost of capital, the value to be used in TEAM, is calculated via Equation (3.9), which incorporates the deductibility of debt.

$$
k=\operatorname{Debtf} * E(r c b) *(1-i t f) * E q u i t y f * E(m) \quad[p . u .](3.9)
$$

where $\quad k=$ the after-tax weighted cost of capital

itf $\approx$ the combined state and federal income tax rate

Debtf $=$ defined above

Equityf $=$ defined above

$E(r c b)=$ defined above

$E(r m)=$ defined above.

Substituting the value of itf calculated in Equation (3.1) and the input variable values used in Equation (3.8) yields the after-tax weighted cost of capital.

$$
\begin{aligned}
k & =(0.32) *(0.053) *(1-0.391)+(0.68) *(0.121) \quad[p .4 .](3.10) \\
& =9.3 \% .
\end{aligned}
$$

The generic industrial/comercial discount rate calculated above is the minimum acceptable rate of return on an investment and includes the historical arithmetic mean value of annual inflation ( 3.15$)$.

\subsubsection{Discount Rates for Municipal and Residential Investments}

Because the cost of a municipal investment in a TES system would most likely be financed out of general tax revenue or by a municipal bond issue, the cost of capital for a municipality can be more easily estimated. The yield-to-maturity of AAR municipal and AAA corporate bonds from 1920 to 1984 were compared (Consolidated Capital Communications Group 1985). It was found 
that over this period the yield-to-maturity on municipal bonds was, on average, 1.27 percentage points less than the yield-to-maturity on corporate bonds. Thus, because the expected nominal return on corporate bonds is $5.3 \%$, the expected nominal return on municipal bonds (and the appropriate nominal discount rate) is $4.0 \%$. No after-tax adjustment is necessary because municipalities don't pay taxes.

Similarly, because a residential investment (new construction) would probably be financed by a home mortgage loan, the mortgage rates and yieldto-maturity on AAA corporate bonds from 1963 to 1984 were compared (U.S. Department of Comnerce 1987). Over this period, mortgage rates exceeded the yieldto-maturity on corporate bond by 0.63 percentage points. Thus, because the expected nominal return on corporate bonds is $5.3 \%$, the expected nominal cost of residential mortgage financing (and the appropriate before-tax discount rate) is 5.9\%. In general, three different income tax rates will apply to individuals in the tax years commencing in 1988: 15\%, 28\%, and 33\%. The middle rate was chosen for calculating the after-tax discount rate because the majority of homeowners have adjusted gross incomes falling in this category. Thus, the nominal after-tax cost of capital or discount rate for residential investments is $(0.059) *(1-0.28)=0.042$ or $4.2 \%$.

In a retrofit situation, the most likely homeowner financing mechanism would be a home equity loan. Recent data indicate that the rate on home equity loans is approximately the same as a conventional 30-year mortgage (Money 1987). Although one might expect the rate to be slightly higher, reflecting a secondary claim on the assets, home equity loans tend to be written for a shorter period of time, which counterbalances the first affect. Thus, the appropriate discount rates for retrofit and new construction scenarios in a residential application are the same.

\subsubsection{Discount Rates for Individual Cash Flow Streams}

The traditional approach to project financial analysis employs a single organization-specific discount rate that is applied to each cash flow of every project. The use of a single discount rate implies that each project has the same overall level of risk. In reality, such would rarely be the case. The risk of a project stems from the variability associated with individual cash 
flows and their relationship to one another. For example, the future tax benefits associated with the depreciation of an investment in TES equipment are fixed once project commences, while the actual energy-related savings may significantly differ from that projected because of uncertainty in the future process operating rate, energy prices, and equipment performance. Clearly the risks associated with different cash flows are not the same and different projects are seldom composed of cash flows of an identical type and magnitude. The theory of using unique discount rates for individual cash flow streams is presented in Appendix 0 along with a discussion of the potential impact on the evaluation of TES technologies. 


\subsection{ENERGY PRICE ASSUMPTIONS}

To assess the costs and benefits of applying TES technology, it is necessary to obtain present and future energy prices to calculate the cost or savings of energy with and without TES. Energy price data were obtained for three sectors: industrial, commercial, and residential. For each sector, prices were obtained for a variety of energy sources as appropriate, including petroleum distillate fuel, natural gas, liquified petroleum gas, residual fuel, metallurgical coal, steam coal, and electricity.

\subsection{HYOROCARBON FUEL PRICES}

Current and projected prices for hydrocarbon fuels were obtained directly from Annual Eneroy Outlook 1986 [Energy Information Administration (EIA) 1987] for 7 discrete years between 1986 and 2000. Tables 4.1, 4.2, and 4.3 give projected prices for three potential scenarios, which differ in their assumptions about future world oil price and econonic growth.

\subsection{ELECTRICITY PRICES}

In general, electric rate structures include charges related to peak power consumption (demand charges, $\$ / \mathrm{kW}$ ) and total energy consumption (energy charges, $\$ / k+h)$. Both of these charges are typically subject to seasonal fluctuations and vary depending on the customer classification. Energy charges also frequently vary with the time of day as well,

The list of special factors included in rate structures and, hence, impacting the final cost per kwh is almost endless. Each utility's rate structure is unique, making characterization of a "typical" rate structure for generic evaluations difficult, if not inpossible. Nevertheless, representative electricity demand and energy charges for use in preliminary evaluations of TES systems were developed. A more detalled characterization of the rate structure may be desirable, depending on the purpose of the evaluation and the level of accuracy required. 
TABLE 4.1. Price of Energy by Source and End-Use Sectors, Base Case (1986 Dollars)

Sector and Fuel

Residential

Distillate fuel ( $\$ / M B t u)$

Natural gas ( $\$ /$ MBtu)

Electricity on-peak ( $\boldsymbol{c} / \mathrm{kWh})$

Electricity off-peak $(\boldsymbol{c} / \mathrm{kWh})$

Electricity flat rate $(t / \mathrm{kWh})$
$1986 \quad 1987$

$\underline{1988}$

1989

$\underline{1990}$

$\underline{1995} \underline{2000}$

$\begin{array}{lllllll}4.46 & 4.71 & 4.91 & 5.16 & 5.40 & 7.90 & 9.81 \\ 5.57 & 5.45 & 5.41 & 5.52 & 5.68 & 7.35 & 9.01 \\ 8.87 & 8.88 & 8.76 & 8.60 & 8.45 & 7.88 & 8.18 \\ 3.61 & 3.61 & 3.57 & 3.50 & 3.44 & 3.21 & 3.33 \\ 6.20 & 6.21 & 6.12 & 6.01 & 5.91 & 5.51 & 5.72\end{array}$

Commercial

$\begin{array}{lrrrrrrr}\text { Distillate fuel (\$/MBtu) } & 3.62 & 3.82 & 3.97 & 4.17 & 4.37 & 6.34 & 7.88 \\ \text { Natural gas (\$/MBtu) } & 4.92 & 4.80 & 4.74 & 4.84 & 4.99 & 6.55 & 8.10 \\ \text { Electricity on-peak ( } \mathbf{c} / \mathrm{kWh}) & 5.62 & 5.64 & 5.58 & 5.48 & 5.39 & 4.99 & 5.19 \\ \text { Electricity off-peak ( } \mathbf{k} / \mathrm{kWh}) & 4.28 & 4.29 & 4.25 & 4.17 & 4.10 & 3.80 & 3.95 \\ \text { Electricity demand charge } & 10.03 & 10.06 & 9.96 & 9.77 & 9.61 & 8.90 & 9.26\end{array}$
$(\$ / \mathrm{kW})$

Industrial

$\begin{array}{llllllll}\text { Distillate fuel (\$/MBtu) } & 3.61 & 3.81 & 3.96 & 4.16 & 4.36 & 6.32 & 7.85 \\ \begin{array}{l}\text { Liquified petroleum gas } \\ \text { (\$/MBtu) }\end{array} & 3.84 & 4.05 & 4.21 & 4.42 & 4.62 & 6.70 & 8.31 \\ \text { Residual fuel (\$/MBtu) } & 2.15 & 2.21 & 2.36 & 2.47 & 2.59 & 3.80 & 4.60 \\ \text { Natural gas (\$MBtu) } & 3.07 & 3.09 & 3.09 & 3.27 & 3.47 & 5.31 & 7.03 \\ \text { Metallurgical coal (\$/MBtu) } & 2.07 & 2.09 & 2.11 & 2.12 & 2.16 & 2.38 & 2.45 \\ \text { Steam coal (\$/MBtu) } & 1.71 & 1.73 & 1.75 & 1.77 & 1.80 & 2.01 & 2.14 \\ \text { Electricity on-peak ( } / \mathrm{kWh}) & 3.90 & 3.90 & 3.85 & 3.77 & 3.71 & 3.41 & 3.56 \\ \text { Electricity off-peak ( } \$ / \mathrm{kWh}) & 2.98 & 2.98 & 2.95 & 2.88 & 2.83 & 2.61 & 2.72 \\ \text { Electricity demand charge } & 6.97 & 6.98 & 6.89 & 6.74 & 6.62 & 6.10 & 6.36\end{array}$
$(\$ / \mathrm{kW})$

Source: (EIA 1987) 
TABLE 4.2. Price of Energy by Source and End-Use Sectors, Low World 0il Price - High Growth Case

(1986 Dollars)

Sector and Fuel

Residential

Distillate fuel (\$/MBtu)

Natural gas ( $\$ / M B t u)$

Electricity on-peak $(\boldsymbol{t} / \mathbf{k} w h)$

Electricity off-peak ( $t / k$ Wh)

Electricity flat rate ( $t / \mathrm{kWh})$

Commercial

Distillate fuel (\$/MBtu)

Natural gas (\$/MBtu)

Electricity on-peak $(\boldsymbol{t} / \mathbf{k} w h)$

Electricity off-peak ( $\phi / \mathrm{kWh})$

Electricity demand charge $(\$ / \mathrm{kW})$

Industrial

Distillate fuel (\$/MBtu)

Liquified petroleum gas $(\$ / \mathrm{MBtu})$

Residual fuel ( $\$ / M B t u)$

Natural gas ( $\$ / M 8 t u)$

Metallurgical coal (\$/MBtu)

Steam coal ( $\$ / M B t u)$

Electricity on-peak ( $\boldsymbol{k} / \mathrm{kWh})$

Electricity off-peak $(\phi / \mathrm{kWh})$

Electricity demand ( $k / \mathrm{k} w h)$ charge $(\$ / \mathrm{kW})$

Source: (EIA 1987) $\underline{1986} \quad \underline{1987} \quad \underline{1988} \quad \underline{1989} \quad \underline{1990} \quad \underline{1995} \quad \underline{2000}$

$\begin{array}{lllllll}4.48 & 3.81 & 4.02 & 4.25 & 4.48 & 6.77 & 8.51 \\ 5.57 & 5.45 & 5.41 & 5.54 & 5.78 & 7.06 & 8.42 \\ 8.87 & 8.83 & 8.69 & 8.53 & 8.38 & 7.71 & 8.02 \\ 3.61 & 3.59 & 3.54 & 3.47 & 3.41 & 3.14 & 3.26 \\ 6.20 & 6.17 & 6.07 & 5.96 & 5.86 & 5.39 & 5.61\end{array}$

$\begin{array}{lllllll}3.64 & 3.17 & 3.34 & 3.53 & 3.72 & 5.53 & 6.94\end{array}$

$\begin{array}{lllllll}4.92 & 4.80 & 4.75 & 4.86 & 5.09 & 6.26 & 7.55\end{array}$

$\begin{array}{lllllll}5.62 & 5.60 & 5.53 & 5.42 & 5.33 & 4.88 & 5.07\end{array}$

$\begin{array}{lllllll}4.28 & 4.27 & 4.21 & 4.13 & 4.06 & 3.71 & 3.86\end{array}$

$\begin{array}{lllllll}10.03 & 10.00 & 9.87 & 9.68 & 9.51 & 8.70 & 9.05\end{array}$

$\begin{array}{lllllll}3.63 & 3.16 & 3.33 & 3.52 & 3.71 & 5.51 & 6.92 \\ 3.86 & 3.37 & 3.54 & 3.74 & 3.94 & 5.85 & 7.33 \\ 2.17 & 1.59 & 1.71 & 1.80 & 1.89 & 2.98 & 3.68 \\ 3.07 & 3.09 & 3.07 & 3.27 & 3.56 & 4.98 & 6.41 \\ 2.07 & 2.09 & 2.11 & 2.12 & 2.17 & 2.39 & 2.48 \\ 1.71 & 1.73 & 1.75 & 1.76 & 1.79 & 2.01 & 2.16 \\ 3.90 & 3.88 & 3.82 & 3.74 & 3.67 & 3.33 & 3.50 \\ 2.98 & 2.97 & 2.92 & 2.86 & 2.80 & 2.55 & 2.67 \\ 6.97 & 6.94 & 6.83 & 6.69 & 6.56 & 5.96 & 6.25\end{array}$


TABLE 4.3. Price of Energy by Source and End-Use Sectors, High World 0i1 Price - Low Growth Case

(1986 Dollars)

Sector and Fuel

Residential

Distillate fuel (\$/MBtu)

$\begin{array}{lll}4.47 & 5.34 & 5.65\end{array}$

$\begin{array}{lll}5.57 & 5.45 & 5.41\end{array}$

5.98

6.33

$5.51 \quad 5.66$

8.87

8.91

8.79

8.62

3.61

3.63

3.58

6.23

6.15

3.51

Electricity flat rate $(\boldsymbol{k} / \mathrm{kWh}) \quad 6.20$

Commercial

$\begin{array}{lrrrrrrr}\text { Distillate fuel (\$/MBtu) } & 3.63 & 4.29 & 4.52 & 4.78 & 5.05 & 7.39 & 9.33 \\ \text { Natural gas (\$/MBtu) } & 4.92 & 4.80 & 4.74 & 4.82 & 4.96 & 6.60 & 9.29 \\ \text { Electricity on-peak ( } \boldsymbol{t} / \mathrm{kWh}) & 5.62 & 5.66 & 5.61 & 5.49 & 5.41 & 5.05 & 5.44 \\ \text { Electricity off-peak ( } / \mathrm{kWh}) & 4.28 & 4.31 & 4.27 & 4.18 & 4.12 & 3.84 & 4.14 \\ \text { Electricity demand charge } & 10.03 & 10.10 & 10.01 & 9.81 & 9.66 & 9.01 & 9.71\end{array}$
$(\$ / \mathrm{kW})$

\section{Industrial}

$\begin{array}{llllllll}\text { Distillate fuel (\$/MBtu) } & 3.62 & 4.28 & 4.51 & 4.77 & 5.04 & 7.36 & 9.30 \\ \begin{array}{l}\text { Liquified petroleum gas } \\ \text { (\$/MBtu) }\end{array} & 3.85 & 4.54 & 4.79 & 5.06 & 5.34 & 7.79 & 9.83 \\ \text { Residual fuel (\$/MBtu) } & 2.17 & 2.65 & 2.85 & 3.03 & 3.21 & 4.75 & 5.85 \\ \text { Natural gas (\$/MBtu) } & 3.07 & 3.09 & 3.12 & 3.27 & 3.46 & 5.35 & 8.28 \\ \text { Metallurgical coal (\$/MBtu) } & 2.07 & 2.09 & 2.11 & 2.11 & 2.15 & 2.37 & 2.43 \\ \text { Steam coal (\$/MBtu) } & 1.71 & 1.74 & 1.75 & 1.76 & 1.79 & 2.01 & 2.13 \\ \text { Electricity on-peak ( } \mathbf{k} / \mathrm{kWh}) & 3.90 & 3.92 & 3.87 & 3.78 & 3.72 & 3.44 & 3.74 \\ \text { Electricity off-peak ( } \mathbf{k} / \mathrm{kWh}) & 2.98 & 2.99 & 2.95 & 2.89 & 2.84 & 2.63 & 2.86 \\ \text { Electricity demand charge } & 6.97 & 7.00 & 6.91 & 6.76 & 6.64 & 6.15 & 6.68\end{array}$
$(\$ / \mathrm{kW})$

Source: (EIA 1987) 
Because of the complexity of characterizing electricity rate structures, it was necessary to obtain more detailed price information than was available in EIA's Annual Energy Outlook 1986. The Electric Rate Book (CSA Energy Consultants 1986) lists all the avallable rate structures for 160 investor-owned utilities that account for three-quarters of all electricity consumed in the U.S. Weighted average (based on each utility's annual sales in $\mathrm{kwh}$ ) on-peak and off-peak electricity prices were calculated from the individual utility's rate structures for residential, commercial, and industrial sectors. Also, weighted average demand charges were calculated for the industrial and commercial sectors. Because only about one-third of the utilities offer tine-of-day pricing to their residential customers, a weighted average flat-rate price was also calculated for that sector. The weighted average electricity rates listed in Tables $4,1,4.2$, and 4.3 are based on marginal rates, representing the cast of the last or next kwh purchased by the customer. Rate data for individual utilities were seasonally averaged, if applicable. The variability of rates among the 160 utilities surveyed is depicted in Table 4,4, which presents the weighted averages, standard deviations, and ranges of rates for each of the different rate classifications in the three sectors.

For the industrial and residential sectors within given utility, the optional rate structure data used were those most favorable to custoners employing TES. Few utilities identify any rate structure as being applicable to commercial customers, so obtaining commercial rates was more complicated than merely selecting from ayallable rates in the Rate Book. Instead, it was noted from Edison Electric Institute data that commercial customers, on average, pay 1.44 times as much for electricity as industrial customers (Edison Electric Institute 1986). The commercial rates shown, then, are equal to the corresponding industrial rates multiplied by 1.44 .

Because the EIA data does not specify demand charges or on-peak and off-peak energy charges, and the Rate Book did not list projected prices, the two data set.s were combined to calculate projected prices for demand and energy charges. 
TABLE 4.4. Summary Electricity Rate Data for Residential, Commercial, and Industrial Sectors (1986 Dollars)

\begin{tabular}{|c|c|c|c|}
\hline Sector & $\begin{array}{l}\text { Weighted } \\
\text { Average }\end{array}$ & $\begin{array}{l}\text { Standard } \\
\text { Deviation }\end{array}$ & Range \\
\hline \multicolumn{4}{|l|}{ Residential } \\
\hline Peak ( $t /$ kwh) & 8.87 & 3.07 & 2.45 to 14.16 \\
\hline off-peak $(t / k W h)$ & 3.61 & 1.56 & 0.92 to 7.81 \\
\hline Flat $(t / k W h)$ & 6.20 & 2.11 & 2.40 to 13.61 \\
\hline \multicolumn{4}{|l|}{ Commercial } \\
\hline Peak $(t / k w h)$ & 5.62 & 2.96 & 0.03 to 18.63 \\
\hline off-peak $(t / k W h)$ & 4.28 & 2.06 & 0.03 to 10.99 \\
\hline Demand charge $(\$ / k W)$ & 10.03 & 6.41 & 2.38 to 58.95 \\
\hline \multicolumn{4}{|l|}{ Industrial } \\
\hline Peak ( $t /$ kwh $)$ & 3.90 & 2.06 & 0.02 to 12.93 \\
\hline $0 f f$-peak $(t / k W h)$ & 2.98 & 1.43 & 0.02 to 7.63 \\
\hline Demand charge $(\$ / \mathrm{kW})$ & 6.97 & 4.45 & 1.65 to 40.94 \\
\hline
\end{tabular}

To calculate projected prices, the 1986 prices from the Rate Book were multiplied by the ratios of the projected future prices over the 1986 price from the Annual Energy Outlook. For example, the base-case price of on-peak electricity for the industrial sector in 1990 was calculated by multiplying $3.90 \mathrm{t} / \mathrm{kWh}$ (1986 price from the Rate Book) times the ratio of $17.04 \$ / M B t u$ (1990 price from the Annual Energy Outlook) divided by 17.93 \$/MBtu (1986 price from the Annual Energy Outlook), to arrive at a projected 1990 price of $3.71 \mathrm{k} / \mathrm{kwh}$ in 1986 dollars.

\subsection{ENERGY PRICE ESCALATION RATES}

In many applications of the TES assessment methodology, it will be easier to enter escalation rates for various energy sources, instead of entering discrete prices for specific years. To facilitate these applications, the data in the Annual Energy Outlook were used to calculate escalation rates for all the energy 
sources listed in Tables $4.1,4.2$, and 4.3. The equation for calculating the escalation rate is:

$$
g=\left(14 \sqrt{\frac{P_{2000}}{P_{1986}}}\right)-1
$$

$$
\text { where } \begin{aligned}
g & =\text { escalation rate } \\
P_{2000} & =\text { price in the year } 2000 \text { (1986 dollars) } \\
P_{1986} & =\text { price in the year } 1986 \\
14 & =2000-1986 .
\end{aligned}
$$

The escalation rates for each oil-price-dependent scenario are listed in Table 4.5. Although these escalation rates are specifically based on projections of price increases between now and the year 2000, they are also recommended as reasonable estimates of escalation beyond the year 2000. As an alternative to using a single escalation rate beyond 1986, the same approach as described above could be applied to the data in Tables $4.1,4.2$, and 4.3 to develop a series of escalation rates covering shorter time intervals. Shown below is a sample calculation of the escalation rate for commercial natural gas in the low oil price scenario.

$$
g=\left(14 \sqrt{\frac{7.55 \$ / M B t u}{4.92 \$ / M B t u}}\right)-1=0.031 \quad \text { [p.u.] }
$$


TABLE 4.5. Annual Escalation Rates for Various Fuels

By Sector - 1986 to 2000

Low 0 il Price - $\quad$ High 0il Price -

Sector and Fuel

Base Case High Growth Case

Low Growth Case

Residential

Distillate fuel

0.060
0.035
-0.006

0.047

0.072

Natural gas

0.030

0.045

Electricity

$-0.007$

$-0.003$

Commercial

Distillate fuel

0.057

0.047

0.070

Natural gas

0.036

0.031

0.046

Electricity

$-0.006$

$-0.007$

$-0.002$

Industrial

Distillate
Liquified petroleum gas
Residual fuel
Natural gas
Metallurgical coal
Steam coal
Electricity

0.057
0.057
0.056
0.061
0.012
0.016
-0.007

0.047

0.070

0.047

0.069

0.038

0.073

0.054

0.073

0.013

0.012

0.017

0.016

$-0.008$

$-0.003$ 


\subsection{PERFORMANCE EVALUATION}

The purpose of this chapter is to establish standard terminology for use in performance characterization conducted as part of PNL's technical assessment studies. The chapter presents a variety of figures-of-merit that can be used to describe the performance of a TES unit. Where possible, the definitions of the figures-of-merit and the terminology were selected to be consistent with the American Society of Heating, Refrigerating, and Air Conditioning Engineers (ASHRAE) standards for testing active sensible TES devices (ANSI/ASHRAE 94-31986) and standards for testing active latent heat storage devices (ANSI/ASHRAE 94-1-1985).

The economic assessment methodology ultimately depends on a performance evaluation of a given concept. While the development of a general performance assessment methodology similar to the economic assessment methodology was beyond the scope of this investigation, the performance figures-of-merit developed in this evaluation will allow uniform reporting of performance analysis results to an economic assessment activity.

The approach used in this study to define and evaluate the various figuresof-merit consisted of:

- developing a generic terminology to be used with any TES system (Section 5.1)

- defining the significant figures-of-merit (Section 5.2)

- presenting relations for the evaluation of each variable in the various figures-of-merit (Section 5.3)

- presenting an example of the use of the figures-of-merit as applied to an aquifer thermal energy storage unit (Section 5.4).

The figures-of-merit discussed in this chapter are suitable for describing the performance of diurnal, industrial, or seasonal TES units and will be used in PNL assessment studies.

\subsection{GENERIC THERMAL ENERGY STORAGE UNIT}

A generic thermal energy storage unit is shown in figure 5.1. The variables are divided into four groups, those associated with the source (subscript s), 


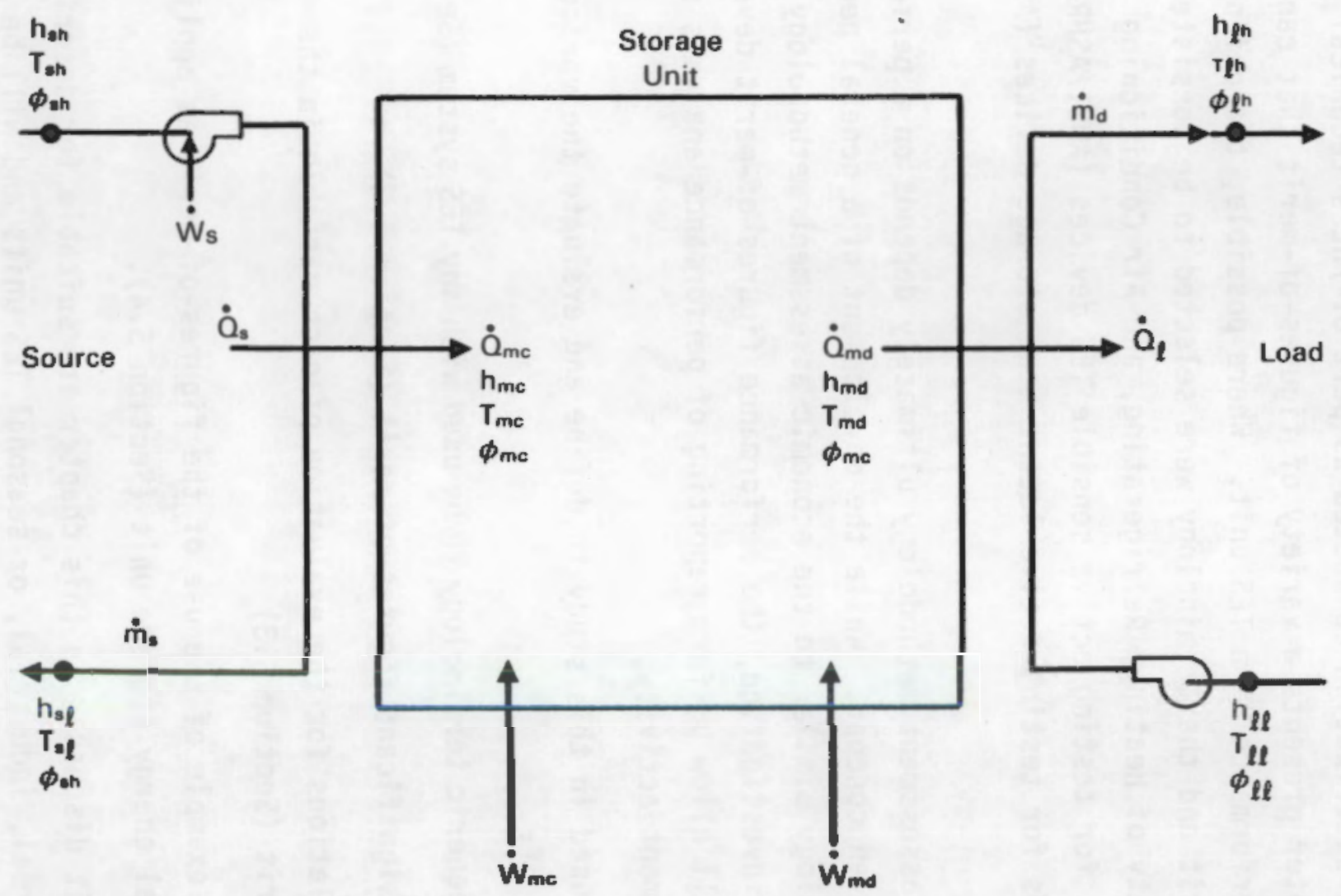

FIGURE 5.1. Generic Thermal Energy Storage Unit 
those associated with the storage media during charge (subscript $\mathrm{mc}$ ), those associated with the storage media during discharge (subscript $m$ ) and those associated with the load (subscript $\ell$ ). A typical storage cycle is shown in Figure 5.2 along with the designated start and stop times for the charge, standby, and discharge phases.

\subsection{FIGURES-OF-MERIT}

The performance of a TES system can be described by any one of the following five figures-of-merit.

- First Law Efficiency, $\eta_{I}=\frac{\text { desired energy output (a) }}{\text { purchased energy input (b) }}$

The use of the First Law Efficiency implies that the load can equally utilize any energy supplied to it (i.e., the temperature of the energy supplied to the load is not a significant variable).

- Second Law Efficiency, $\eta_{I I}=\frac{\text { availability output }}{\text { availability input }}$ (also called effectiveness)

This figure-of-merit includes a measure of the quality of the energy flows including the return flows to the TES unit.

- Useful Storage Factor, $\boldsymbol{\beta}_{\text {stor }}=\frac{\text { actual maximum storage capacity }}{\text { theoretical maximum storage capacity }}$

(a) "Desired output" is the useful output of the device that is of interest to the user.

(b) "Purchased inputs" are inputs whose acquisition requires the user to expend resources. Examples include purchased thermal energy for charging storage and purchased pump or fan power. 


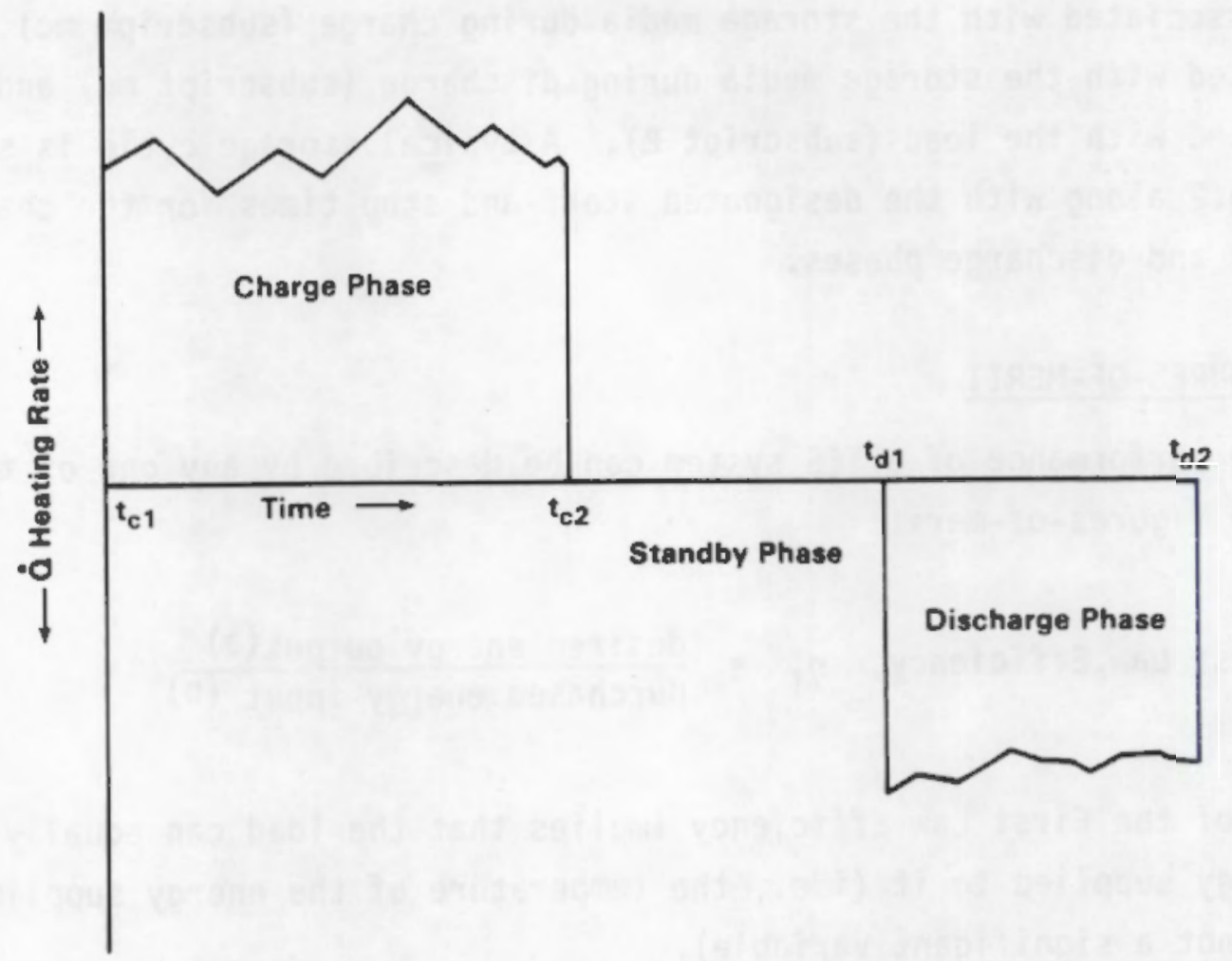

FIGURE 5.2. Definition of Storage Cycle

This factor shows how much of the theoretical storage capacity can actually be utilized in a real installation. It indicates how much excess capacity (based on theoretical storage capacity) must be included to deliver a specified load.

- Energy Storage Density, ESD $=\frac{\text { desired energy output }}{\text { volume of storage media }}$

This factor reports the density of energy storage in the TES device. A high value of ESD indicates very dense storage of energy implying a compact storage device.

- Volume Recovery Factor, $V F=\frac{\text { volume of recovered aquifer fluid }}{\text { volume of injected aquifer fluid }}$

The Volume Recovery Factor is a significant figure-of-merit for aquifer thermal energy storage systems. It indicates the fraction of stored water that can be recovered from an aquifer. 
The First Law Efficiency has the disadvantage of not including a measure of the quality of the energy flows. Consequently, high-quality electrical energy to drive pumps is weighted equally with low-temperature thermal energy. The Second Law Efficiency is often the most useful measure of performance because it appropriately treats the quality of the energy being transferred. A more detailed discussion of availability is presented in Appendix $E$. The storage cycle can be modeled with three component efficiencies and one overall efficiency. Table 5.1 summarizes the significant figures-of-merit, including overall system efficiencies ("round trip efficiency") and component efficiencies. Table 5.2 indicates the loss mechanisms included in each efficiency. In the following sections, procedures for evaluating the various terms in each efficiency definition will be presented.

\subsection{EVALUATION OF HEAT, WORK, AND AVAILABILITY TERMS}

The figures-of-merit presented in Section 5.2 apply to any TES unit, but the evaluation of the various heat, work, and availability terms in the figuresof-merit will depend on the type of system being analyzed. Four generic types of TES systems are presented in Figure 5.3. The first system stores therma1 energy as sensible heat and includes a charge and discharge heat exchanger. This implies that at least one component of storage media can be moved from the media containment to the heat exchangers. Examples of this type of system would be an aquifer thermal energy storage (ATES) facility or a molten salt sensible heat storage unit. The second system is similar except that thermal energy is stored in the media as latent heat. The third system stores thermal energy as sensible heat but without external heat exchangers so that the media is not circulated out of the containment. A checker stove is an example of the third system. The fourth system is similar to the third except that the media undergoes a phase change so that some fraction of the stored thermal energy is stored as latent heat. An example of this approach is a TES system using the composite phase-change material developed by IGT (Petri et al. 1986).

The type of TES concept being analyzed will deternine the method used to evaluate; energy transferred to the storage media during the charge phase $\left(Q_{m c}\right)$, energy transferred from the storage media during the discharge phase 


\section{TABLE 5.1. Figures-of-Merit}

First Law Efficiency

Charge Efficiency

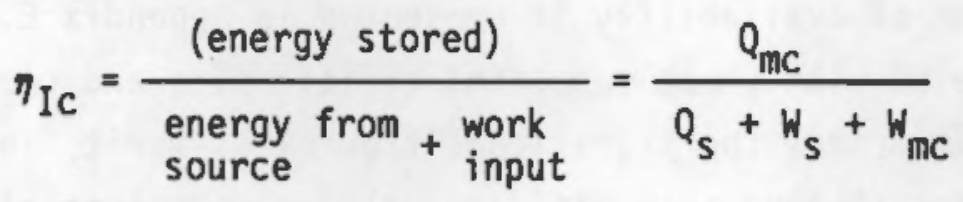

Standby Efficiency

$$
\eta_{\text {Is }}=\frac{\text { (energy for discharge) }}{\text { (energy stored) }}=\frac{Q_{m d}}{Q_{m c}}
$$

Discharge Efficiency

$$
\eta_{I d}=\frac{\text { (energy to load) }}{\begin{array}{l}
\text { energy for } \\
\text { discharge }
\end{array}+\begin{array}{l}
\text { work } \\
\text { input }
\end{array}}=\frac{Q_{l}}{Q_{m d}+W_{l}+W_{m d}}
$$

"Round Trip" Efficiency

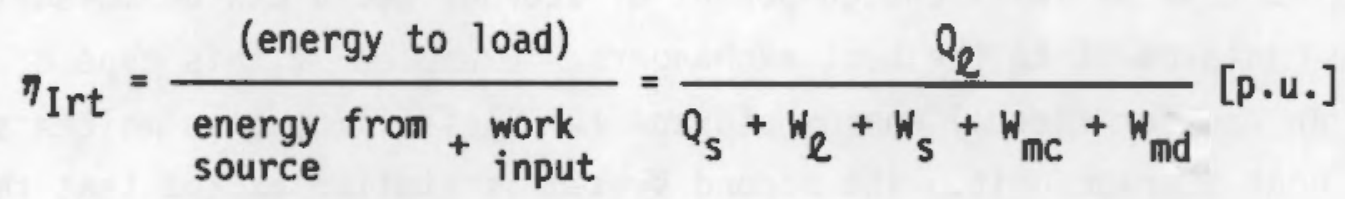

Second Law Efficiency

Charge Efficiency

$$
\eta_{\text {IIc }}=\frac{\text { (availability stored) }^{(a)}}{\begin{array}{l}
\text { availability } \\
\text { from source }
\end{array}+\begin{array}{c}
\text { work } \\
\text { input }
\end{array}}=\frac{w_{\mathrm{mc}}+W_{\mathrm{s}}+W_{\mathrm{mc}}}{\Phi_{\mathrm{s}}}
$$

(a) Currently there is no standard terminology for second law analysis. Availability is also referred to as exergy or essergy. 
TABLE 5.1. (Cont'd)

Standby Efficiency

$$
\eta_{I I s}=\frac{\text { (availability for discharge) }}{\text { (availability stored) }}=\frac{\Phi_{m d}}{\Phi_{m c}}
$$

Discharge Efficiency

$$
\eta_{\text {IId }}=\frac{\text { (availability to load) }}{\begin{array}{l}
\text { availability } \\
\text { for discharge }
\end{array}+\begin{array}{c}
\text { work } \\
\text { input }
\end{array}}=\frac{\Phi_{\mathrm{md}}+W_{\mathrm{md}}+W_{l}}{\Phi}
$$

Round Trip Efficiency

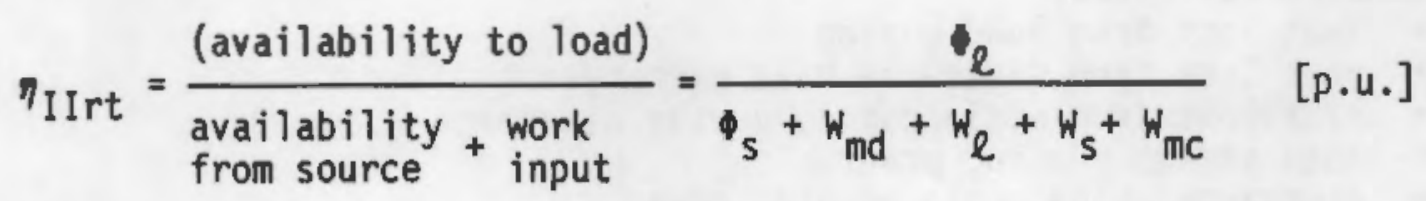

Maximum Charge Rate

$$
Q_{\max }=\text { maximum value of } Q_{m c}
$$

Maximum Discharge Rate

$$
Q_{\text {max }_{d}}=\text { maximum value of } Q_{m d}
$$

Useful Storage Factor

$$
\rho_{\text {stor }}=\frac{\text { (actual maximum storage capacity) }}{\text { theoretical maximum storage capacity }}=\frac{Q_{l}}{\mathrm{TSC}} \quad\left[\frac{\mathrm{kJ}}{\mathrm{m}^{3}}\right]
$$

Energy Storage Density

$$
\text { ESD }=\frac{\text { (desired energy output) }}{\text { (volume of storage media) }}=\frac{Q_{l}}{v_{m d}}
$$

Volume Recovery Factor (for ATES systems)

$$
V_{F}=\frac{\text { (volume of recovered aquifer fluid) }}{\text { (volume of injected aquifer fluid) }}=\frac{v_{m d}}{v_{m c}}
$$


TABLE 5.2. Losses Included in Efficiencies

\section{First Law Efficiency}

Charge Efficiency

- heat loss from source stream piping

- heat loss from charging heat exchanger

- heat loss from media piping during charge

- source stream pumping power

- charge phase media pumping power

- energy remaining in source stream (see Section 5.3.1)

Standby Efficiency

- heat loss from storage during standby

Discharge Efficiency

- heat loss from load piping

- heat loss from discharge heat exchanger

- heat loss from media piping during discharge

- load stream pumping power

- discharge phase media pumping power

\section{Second Law Efficiency}

Charge Efficiency

- availability loss due to heat loss from source stream piping

- availability loss due to heat loss from charging heat exchanger

- availability loss due to heat loss from media piping during charge

- availability loss due to temperature difference in heat exchanger

- source stream pumping power

- charge phase media pumping power

- availability remaining in source stream (see Section 5.3.1)

Standby Efficiency

- availability loss due to heat loss from storage during discharge

- availability loss due to internal heat transfer (degradation of stratified storage)

Discharge Efficiency

- availability loss due to heat loss from load piping

- availability loss due to heat loss from discharge piping

- availability loss due to heat loss from media piping during discharge

- availability loss due to temperature difference in heat exchanger

- load stream pumping power

- discharge phase media pumping power 


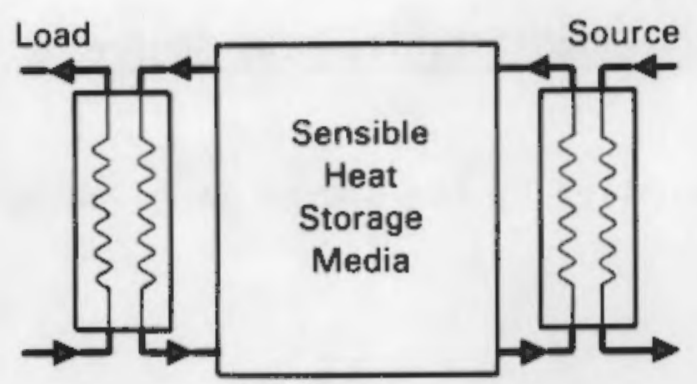

Sensible Heat Storage With External Heat Exchange

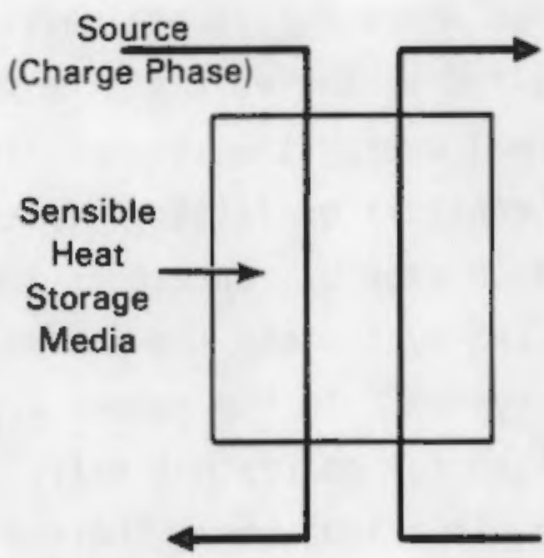

Sensible Heat Storage Without External Heat Exchange

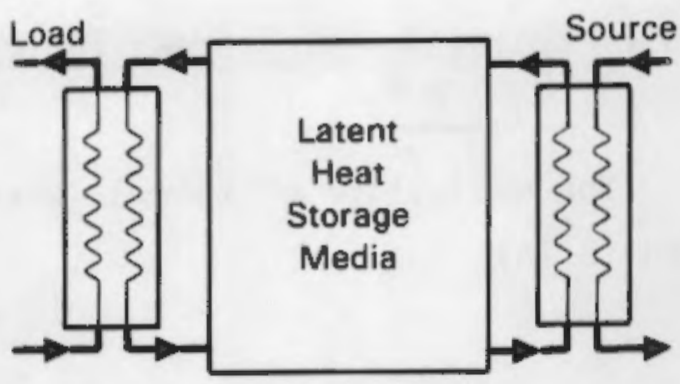

Latent Heat Storage With External Heat Exchange

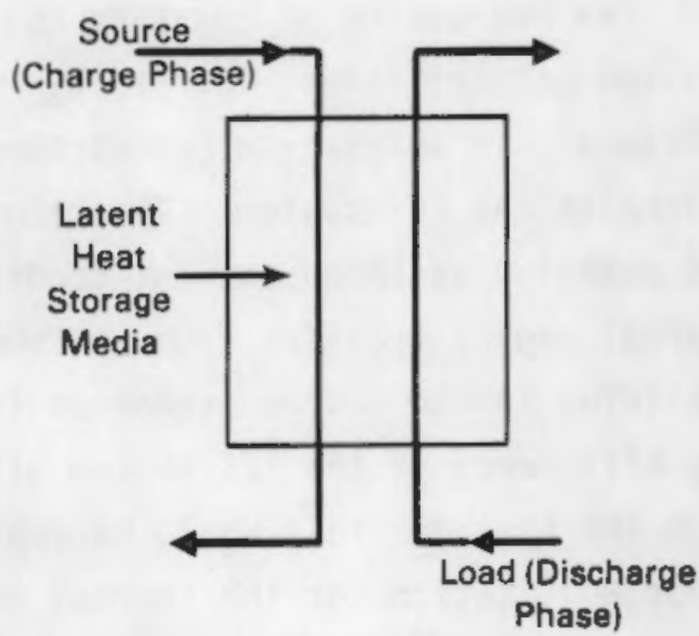

Latent Heat Storage Without External Heat Exchange

FIGURE 5.3. Generic Thermal Storage System Arrangements

(Qmd), availability transferred to the storage media during the charge phase $\left(\Phi_{\mathrm{mc}}\right)$, and availability transferred from storage during the discharge phase $\left(\Phi_{\mathrm{n}}\right)$. The evaluation of the other variables does not depend on the type of storage system being analyzed. 


\subsubsection{Evaluation of Thermal Energy and Availability from the Source $\left(Q_{s}\right.$ and $\left.\phi_{s}\right)$}

The evaluation of thermal energy supplied by the source is given by Equation (5.14)

$$
Q_{s}^{(a)}=\int_{c 1}^{t}{ }_{c 2}^{c 2} h_{s}\left(h_{s h}-h_{s l}\right) d t
$$

The evaluation of Equation (5.14) depends on where $h_{s e}$ is evaluated. There are two possibilities. First, $h_{S \ell}$ can be evaluated at the exit of the heat exchanger, in which case $Q_{s}$ represents the thermal energy transferred from the source to the TES system. The second approach consists of letting $h_{s}$ e equal the enthalpy based on ambient conditions, in which case $Q_{s}$ represents the thermal energy transfer from the source to the TES system and the thermal energy remaining in the source stream as it exits the system. In the second approach, the efficiency of the TES system will be penalized for energy not extracted from the source. This would be appropriate for situations where there is no other application for the thermal energy in the source stream. The first approach would be more appropriate if the thermal energy in the source stream could be used in some other process. Both approaches have disadvantages and the selection will depend on the details of the analysis. In either case, an analys is should explicitly state which approach is being used to evaluate $h_{s e}$.

(a) All major energy flows are defined by an integral. This allows the variables to change during the phase being analyzed. In practical calculations the integral would be replaced and an approximation, which would consist of a summation of the results for a number of finite time steps. An example would be the following:

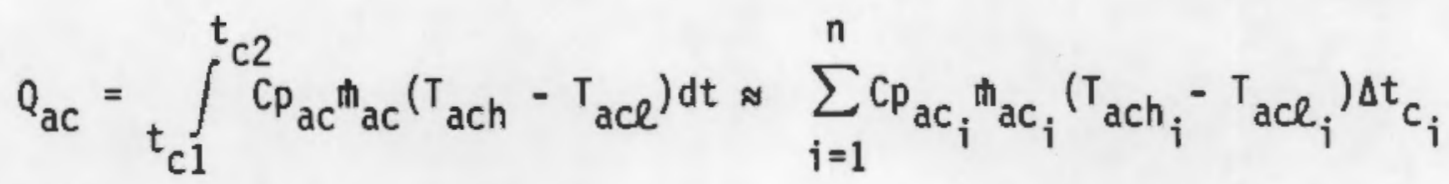

The accuracy of the approximation will increase as $n$ is increased (resulting in smaller time steps). 
Availability from the source is defined by Equation (5.15)

$$
\phi_{s}=\int_{t=1}^{t} c 2 \quad m_{s}\left(\phi_{s h}-\phi_{s \ell}\right) d t
$$

As with the evaluation of $Q_{S}, \phi_{S}$ will depend on the evaluation of $\phi_{s}$. $\phi_{S R}$ can either be evaluated at the exit of the heat exchanger or at ambient conditions. Because of the definition of availability (Appendix E), if $\phi_{S}$, is evaluated at ambient conditions, it will equal 0.0 . The selection of $\phi_{\mathrm{s}}$ will be determined by the details of the specific analysis. In either case, an analysis should explicitly state which approach is being used.

\subsubsection{Evaluation of Thermal Energy and Availability Supplied to Storage $\left(Q_{m c}\right.$ and $\left.\phi_{m c}\right)$}

The evaluation of thermal energy supplied to storage depends on the TES system. For systems with heat exchangers (i.e., moving storage media) Qmc and $\Phi_{m c}$ can be evaluated using the enthalpy or availability change of the media as it passes through the heat exchanger. The evaluation equations for sensible heat storage are given by Equations (5.16) and (5.17). The equations for latent heat storage are given by Equations (5.18) and (5.19).

Sensible Heat

$$
Q_{m c}=\int_{c 1}^{t} c 2 C_{m c} m_{m c}\left(T_{m c h}-T_{m c e}\right) d t
$$

Equation (5.16) was simplified by substituting CPAT for $\Delta$ h because thermal energy was only being stored as sensible heat. When latent heat effects are important, this relationship is no longer valid and ( $\left.h_{\text {mch }}-h_{m c e}\right)$ must be used.

$$
\phi_{m c}=\int_{t}^{t}{ }_{c 1}^{c 2} m_{m c}\left(\phi_{m c h}-\phi_{m c e}\right) d t
$$




\section{Latent Heat}

$$
\begin{aligned}
& Q_{m c}=\int_{t}^{t} \int_{m c}^{c 2} t_{m c}\left(h_{m c h}-h_{m c e}\right) d t \\
& \Phi_{m c}=\int_{t}^{t}{ }^{c 2} t_{m c}\left(\phi_{m c h}-\phi_{m c l}\right) d t
\end{aligned}
$$

When the media is fixed, $Q_{\mathrm{mc}}$ and $\Phi_{\mathrm{mc}}$ must be evaluated by determining the media energy or availability content of the media. This may be a challenging calculation, particularly for latent heat storage. The evaluation equations for sensible heat storage are given by Equations (5.20) and (5.21). The evaluation equations for latent heat storage are given by Equations (5.24) and (5.25).

Sensible Heat

$$
\begin{aligned}
& Q_{m c}=\sum_{j=1}^{p} \iiint \rho_{m c}{ }_{j} C \rho_{m c}\left(T_{m c h_{j}}-T_{m c e_{j}}\right) d v \\
& \Phi_{m c}=\sum_{j=1}^{p} \iiint \rho_{m c}\left(\phi_{m c h_{j}}-\phi_{m c e_{j}}\right) d v
\end{aligned}
$$

where $\mathrm{j}$ indicates the storage media component and the triple integral indicates a volume integral. If the storage media consists of one component, Equations $(5.20)$ and $(5.21)$ reduce to Equations (5.22) and (5.23).

$$
Q_{m c}=\iiint \rho_{m c} C P_{m c}\left(T_{m c h}-T_{m c l}\right) d V
$$




$$
\phi_{m c}=\iiint \rho_{m c}\left(\phi_{m c h}-\phi_{m c e}\right) d v
$$

The volume integral used in Equations (5.20), (5.21), (5.22), and (5.23) indicates that $Q_{m c}$ or $\Phi_{m c}$ will equal the local stored energy or availability integrated over the storage volume.

Latent Heat Storage

$$
\begin{aligned}
& Q_{m c}=\sum_{j=1}^{p} \iiint \rho_{m c_{j}}\left(h_{m c h_{j}}-h_{m c e_{j}}\right) d v \\
& \Phi_{m c}=\sum_{j=1}^{p} \iiint \rho_{m c_{j}}\left(\phi_{m c h_{j}}-\phi_{m c e_{j}}\right) d v
\end{aligned}
$$

For one storage component, Equation (5.24) reduces to Equation (5.26) while Equation (5.25) reduces to Equation (5.23).

$$
Q_{m c}=\iiint \rho_{m c}\left(h_{m c h}-h_{m c e}\right) d V
$$

In many cases the evaluation of Equations (5.20), (5.21) or (5.24) will be difficult, but if the heat exchange process is adiabatic (which is usually a good assumption), Qmc will equal the energy given up by the source. For this case, Q Q can be evaluated using Equation (5.27)

$$
Q_{m c}=\int_{t c 1}^{t} m_{m s}^{c 2}\left(h_{s h}-h_{s l}\right) d t
$$

Note that a similar method cannot be used to evaluate $\Phi_{\mathrm{mc}}$ because even for an adiabatic heat exchanger, irreversibilities will insure that $\Phi_{\mathrm{s}} \neq \Phi_{\mathrm{mc}}$. 
5.3.3 Evaluation of Thermal Energy and Availability Delivered From Storage $\left(Q_{m d}\right.$ and $\left.\phi_{m d}\right)$

The evaluation of the thermal energy and availability delivered from storage also depends on the type of system being considered. For systems with heat exchangers (i.e., moving storage media), Q $Q_{\mathrm{mc}}$ and $\Phi_{\mathrm{mc}}$ can be evaluated using the enthalpy or availability change as the media passes through the heat exchanger. The evaluation equations for sensible heat storage are given by Equations (5.28) and (5.29). The evaluation equations for latent heat storage are given by Equations (5.30) and (5.31).

Sensible Heat Storage

$$
\begin{aligned}
& Q_{m d}=\int_{t_{d 1}}^{t} C p_{m d}{ }_{m d}\left(T_{m d h}-T_{m c l}\right) d t \\
& \Phi_{m d}=\int_{t_{d 1}}^{t} m_{m d}^{d 2}\left(\phi_{m d h}-\phi_{m c l}\right) d t
\end{aligned}
$$

Latent Heat Storage

$$
\begin{aligned}
& Q_{m d}=\int_{t d 1}^{t} d 2 m_{m d}\left(h_{m d h}-h_{m c l}\right) d t \\
& \Phi_{m d}=\int_{t}^{t}{ }_{d 1}^{d 2} m_{m d}\left(\phi_{m d h}-\phi_{m c l}\right) d t
\end{aligned}
$$

The definitions of $\Phi_{m d}$ and $Q_{m}$ assume that the TES unit operates in a cycle and must return to its initial thermodynamic state ( $T_{m c l}, \phi_{m c l}, h_{m c l}$ ). This implies that any energy not transferred to the load is lost to the surroundings so that the TES unit returns to the initial state. 
When the media is fixed, as in a direct-contact checker stove, Qmd and $\Phi_{\mathrm{mc}}$ must be evaluated by determining media decrease in energy or availability during discharge. This may be a challenging calculation. The evaluation equations for sensible heat storage are given in Equations (5.32) and (5.33). The evaluation equations for latent heat storage are given in Equations (5.36) and (5.37).

Sensible Heat Storage

$$
\begin{aligned}
Q_{m d} & =\sum_{j=1}^{p} \iiint \rho_{m d_{j}} C p_{m d}\left(T_{m d h_{j}}-T_{m c e_{j}}\right) d V \quad[k J] \\
\Phi_{m d} & =\sum_{j=1}^{p} \iiint \rho_{m d}\left(\phi_{m d h_{j}}-\phi_{m c e_{j}}\right) d V
\end{aligned}
$$

where $\mathbf{j}$ indicates the storage media component. If the storage media consists of one component, Equations (5.32) and (5.33) reduce to Equations (5.34) and (5.35).

$$
\begin{aligned}
Q_{m d} & =\iiint \rho_{m d} C p_{m d}\left(T_{m d h}-T_{m c l}\right) d V \\
\phi_{m d} & =\iiint \rho_{m d}\left(\phi_{m d h}-\phi_{m c l}\right) d V
\end{aligned}
$$

The volume integrals used above indicate that $Q_{m d}$ or $\Phi_{m d}$ are evaluated by integrating the local discharged energy or availability over the storage volume. Latent Heat Storage

$$
Q_{m d}=\sum_{j=1}^{p} \iiint \rho_{m c}\left(h_{m c h_{j}}-h_{m c e_{j}}\right) d v
$$




$$
\Phi_{m d}=\sum_{j=1}^{p} \iiint \rho_{m d_{j}}\left(\phi_{m d h_{j}}-\phi_{m c e_{j}}\right) d v
$$

For one storage component, Equation (5.36) reduces to Equation (5.38) while Equation (5.37) reduces to Equation (5.35).

$$
Q_{m d}=\iiint \rho_{m d}\left(h_{m d h}-h_{m c l}\right) d v
$$

\subsubsection{Evaluation of Thermal Energy and Availability Supplied to the Load $\left(Q_{l}\right.$ and $\left.\phi_{l}\right)$}

The evaluation of net thermal energy absorbed by the load is given by Equation (5.39).

$$
Q_{l}=\int_{t_{d 1}}^{t} d 2
$$

The net availability supplied to the load is given by Equation (5.40).

$$
\phi_{\ell}=\int_{t_{d 1}}^{t} d 2 m_{\ell}\left(\phi_{\ell h}-\phi_{\ell l}\right) d t
$$

\subsubsection{Evaluation of Work Inputs}

As shown in Figure 5.1, there are four possible work inputs to the generic TES system: work inputs associated with the source $\left(\dot{W}_{S}\right)$, work inputs associated with the TES media during the charge phase ( $\left.\dot{W}_{\mathrm{mc}}\right)$, work inputs associated with the TES media during the discharge phase ( $\left.\dot{H}_{m d}\right)$ and work inputs associated 
with the load $\left(\dot{H}_{\ell}\right)$. Examples of work inputs include pump power, fan power, and other electric power requirements. The four work inputs are defined by Equations (5.41) through (5.44).

$$
\begin{aligned}
& w_{s}=\int_{c 1}^{t} c 2 \dot{w}_{s} d t \\
& w_{m c}=\int_{t}^{t c 2} \dot{w}_{m c} d t \\
& w_{m d}=\int_{d 1}^{t} d 2 \dot{w}_{m d} d t \\
& w_{l}=t_{d 1}^{t} d 2 \dot{w}_{l} d t
\end{aligned}
$$

\subsection{APPLICATION OF FIGURES-OF-MERIT TO AQUIFER THERMAL ENERGY STORAGE}

As an example of the use of the performance characteristics discussed in this report, the figures-of-merit will be evaluated for an ATES system. The ATES system is shown in Figure 5.4. This thermal energy storage concept stores thermal energy as sensible heat and includes charge and discharge heat exchangers.

\subsubsection{Charge Efficiency}

The First Law Charge Efficiency definition is given by Equation (5.1). The variables in Equation (5.1) can be evaluated using Equations (5.14), (5.41), (5.42), and (5.16). For a steady-state charging phase, Equations (5.14), $(5.41),(5.42)$, and $(5.16)$ reduce to Equations $(5.45),(5.46),(5.47)$, and (5.48). 


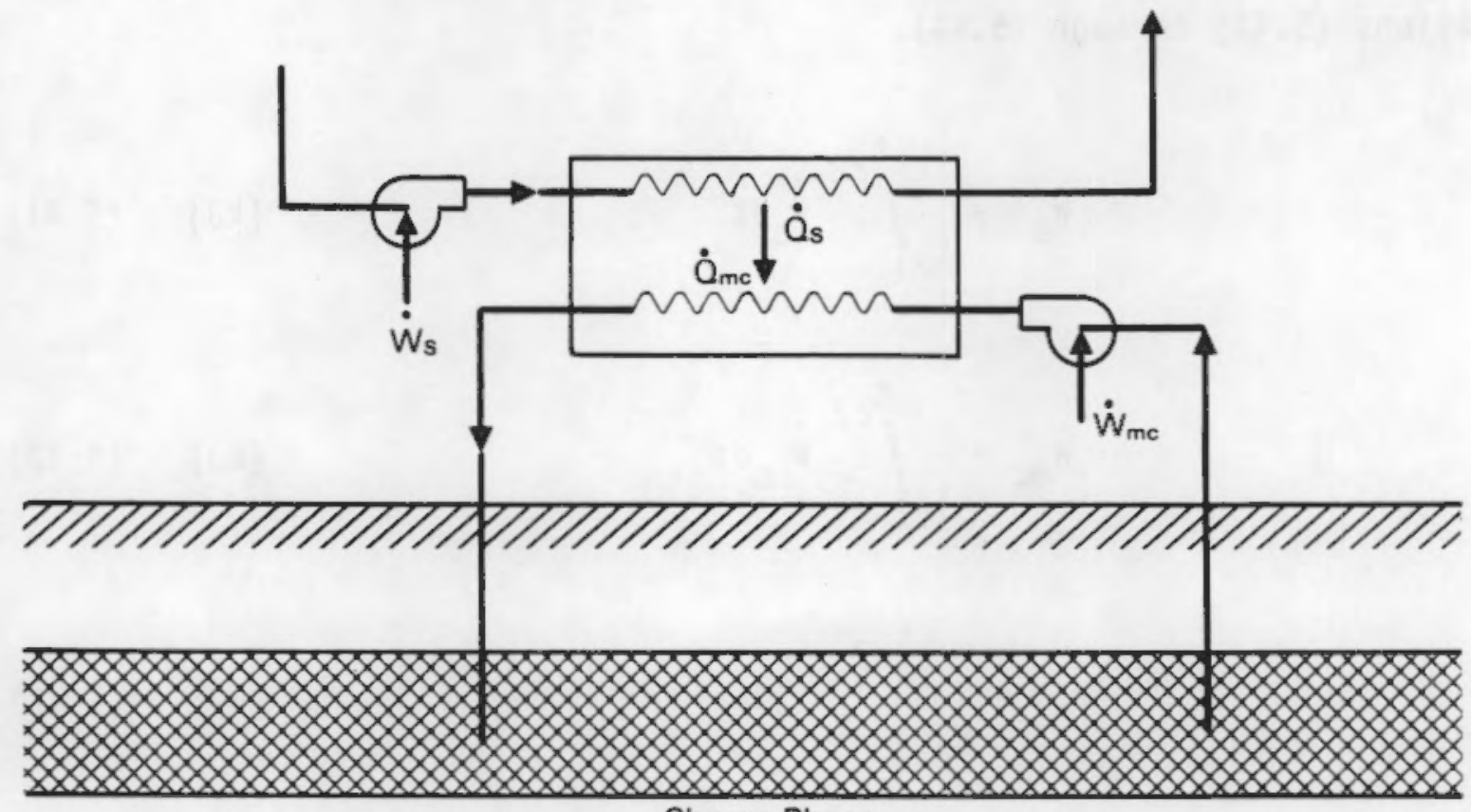

Charge Phase

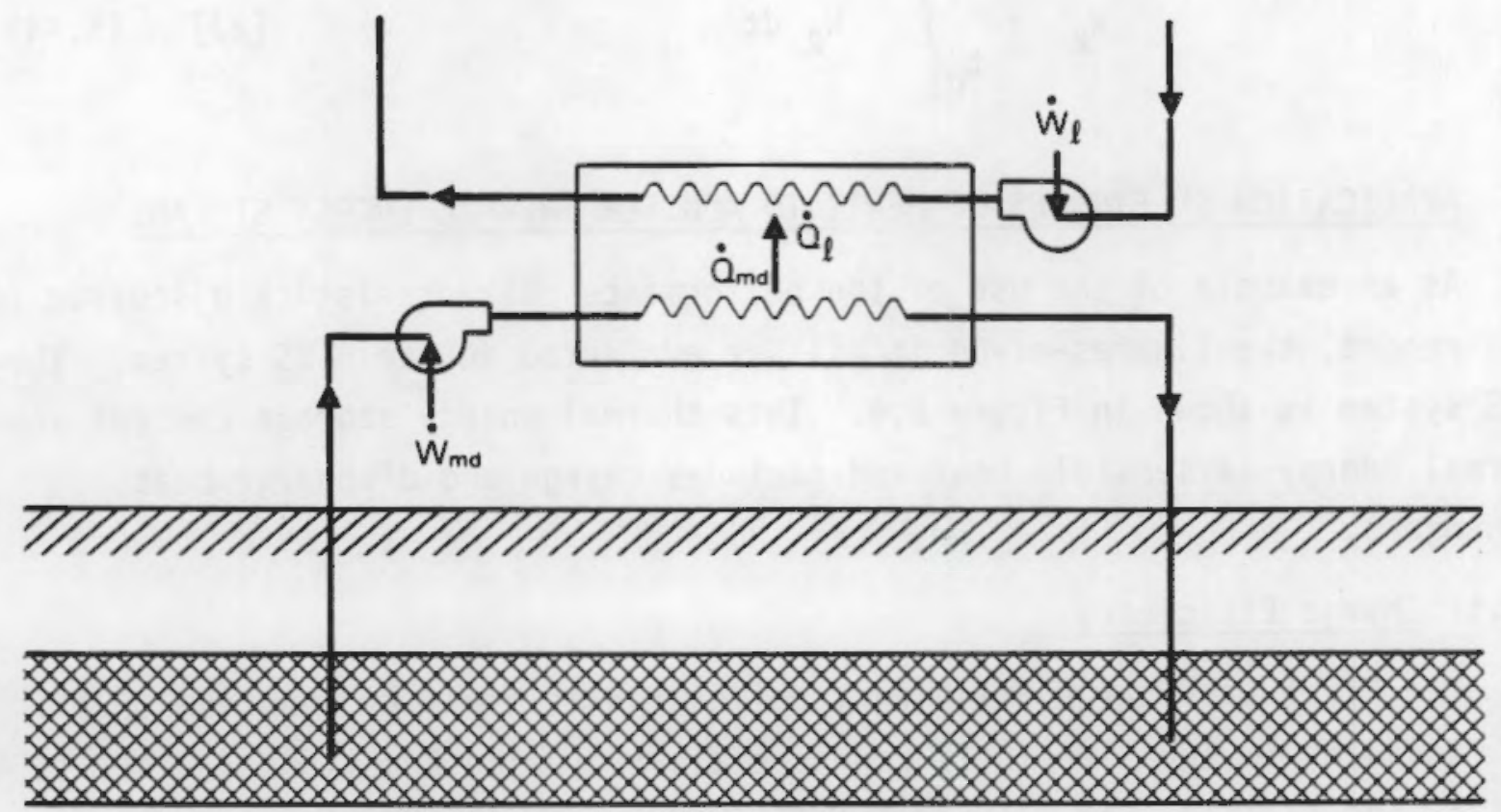

Discharge Phase

FIGURE 5.4. Typical Aquifer Thermal Energy Storage System 


$$
\begin{aligned}
& Q_{m c}=C_{m c} i_{n n c}\left(T_{m c h}-T_{m c e}\right) \Delta T_{c} \\
& Q_{5}=\dot{m}_{5}\left(h_{5 h}-h_{52}\right) \Delta T_{C} \\
& H_{S}=\dot{W}_{S} \Delta T_{C} \\
& W_{a c}=W_{a c} A T_{C}
\end{aligned}
$$

Substituting Equations $(5.45),(5.46),(5.47)$, and (5.48) into Equation (5.1) yields Equation (5.49).

$$
\eta_{1 C}=\frac{c p_{m c} \dot{m}_{m c}\left(T_{m c h}-T_{m c}\right)}{\dot{m}_{s}\left(h_{s h}-h_{s e}\right)+\dot{w}_{s}+\dot{w}_{g c}}
$$

The Second Law Charge Efficiency definition is given by Equation (5.5). The variables in Equation (5.5) can be evaluated using Equations (5.15), (5.41). (5.42), and (5.17). For a steady-state charge phase, Equations $(5.15),(5.41)$. (5.42), and $(5.17)$ reduce to Equations $(5.50),(5.47),(5.48)$, and $(5.51)$,

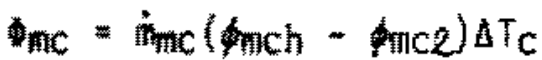

$$
\begin{aligned}
& \Phi_{s}=m_{s}\left(b h-b_{s 2}\right) \Delta T_{c}
\end{aligned}
$$

Substituting Equations $(5.50),(5.47),(5.48)$, and (5.51) into Equation (5.5) yields Equation (5.52).

$$
\eta_{I I C}=\frac{\dot{m}_{m c}\left(\phi_{m c h}-\phi_{m c l}\right)}{\dot{m}_{s}\left(\phi_{s h}-\phi_{s l}\right)+\dot{w}_{s}+\dot{w}_{a c}}
$$




\subsubsection{Standby Efficiency}

The First Law Standby Efficiency definition is given by Equation (5.2). The variables in Equation (5.2) can be evaluated using Equations (5.16) and (5.27). For a steady-state charge and discharge phase, Equations (5.16) and (5.27) reduce to Equations $(5.45)$ and $(5.53)$.

$$
Q_{\text {md }}=C_{\text {mdd }} \text { mind }\left(T_{\text {mdh }}-T_{\text {mcl }}\right) \Delta T_{d}
$$

Substituting Equations $(5.45)$ and $(5.53)$ into Equation $(5.2)$ yields Equation $(5.54)$.

$$
\eta_{\text {IS }}=\frac{\dot{m}_{m d}\left(T_{m d h}-T_{m c l}\right) \Delta T_{d}}{\text { mac }_{\text {mc }}\left(T_{\text {mch }}-T_{m c l}\right) \Delta T_{c}}
$$

The Second Law Standby Efficiency definition is given by Equation (5.6). The variables in Equation (5.6) can be evaluated using Equations (5.17) and (5.29). For a steady-state charge and discharge phase, Equations (5.17) and $(5.29)$ reduce to Equations $(5.50)$ and $(5.55)$.

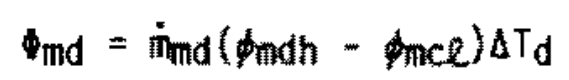

Substituting Equations (5.50) and (5.55) into Equation (5.6) yields Equation $(5.56)$.

$$
\eta_{\text {IIS }}=\frac{\dot{\pi}_{m d}\left(\phi_{\text {mdh }}-\phi_{\text {mce }}\right) \Delta T_{d}}{i_{m e}\left(\phi_{\text {mch }}-\phi_{m c l}\right) \Delta T_{c}}
$$

\subsubsection{Discharge Efficiency}

The First Law Discharge Efficiency is defined by Equation (5.3). The variables in Equation 5.3 can be evaluated using Equations $(5.39),(5.43),(5.44)$, 
and (5.28). For a steady-state discharge phase, these equations reduce to Equations (5.53), (5.57), (5.58), and (5.59).

$$
\begin{gathered}
Q_{l}=\dot{m}_{\ell}\left(h_{l h}-h_{l \ell}\right) \Delta T_{d} \\
W_{l}=\dot{W}_{\ell} \Delta T_{d} \\
W_{m d}=\dot{W}_{m d} \Delta T_{d}
\end{gathered}
$$

Substituting Equations (5.53), (5.57), (5.58), and (5.59) into Equation (5.3) yields Equation (5.60).

$$
\eta_{I D}=\frac{\dot{m}_{l}\left(h_{h \ell}-h_{l \ell}\right)}{\dot{m}_{m d} C p_{m d}\left(T_{m d h}-T_{m c l}\right)+\dot{w}_{l}+\dot{w}_{m d}}
$$

The Second Law Discharge Efficiency definition is given by Equation (5.7). The variables in Equation (5.7) can be evaluated using Equations (5.40), (5.43), (5.44), and (5.29). For a steady-state charge phase, Equations (5.40), (5.43), (5.44), and (5.29) reduce to Equations (5.61), (5.58), (5.59), and (5.55).

$$
\Phi_{l}=\dot{m}_{\ell}\left(\phi_{l h}-\phi_{l \ell}\right) \Delta T_{d}
$$

Substituting Equations (5.55), (5.58), (5.59), and (5.61) into Equation (5.7) yields Equation (5.62).

$$
\eta_{I I D}=\frac{\dot{m}_{\ell}\left(\phi_{\ell h}-\phi_{\ell \ell}\right)}{\dot{m}_{m d}\left(\phi_{m d h}-\phi_{m c l}\right)+\dot{w}_{\ell}+\dot{w}_{m d}}
$$

\subsection{4 "Round Trip" Efficiency}

The First Law Round Trip Efficiency is defined by Equation (5.4). The variables in Equation (5.4) are evaluated using Equations (5.14), (5.39), $(5.41),(5.42),(5.43)$, and (5.44). For steady-state charge and discharge 
phases, these equations reduce to Equations $(5.46),(5.57),(5.47),(5.48)$, (5.58), and (5.59). Substituting them into Equation (5.4) yields Equation $(5.63)$.

$$
\eta_{I r t}=\frac{\dot{m}_{l}\left(h_{l h}-h_{l l}\right) \Delta T_{d}}{\left[\dot{m}_{s}\left(h_{s h}-h_{s l}\right)+\dot{w}_{m c}+\dot{w}_{s}\right] \Delta T_{c}+\left(\dot{w}_{m d}+\dot{w}_{l}\right) \Delta T_{d}} \quad[p . u .]
$$

The Second Law Round Trip Efficiency is defined by Equation (5.8). The variables in Equation $(5.8)$ are evaluated using Equations $(5.15),(5.40)$, (5.41), (5.42), (5.43), and (5.44). For steady-5tate charge and discharge phases, these equations reduce to Equations $(5.51),(5.61),(5.47),(5.48)$, (5.58), and (5.59). Substituting them into Equation (5.8) yields Equation (5.64).

$$
\eta_{\text {Irt }}=\frac{\dot{m}_{l}\left(\phi_{\ell h}-\phi_{l \ell}\right) \Delta T_{d}}{\left[\dot{m}_{s}\left(\phi_{s h}-\phi_{s l}\right)+\dot{w}_{n c}+\dot{w}_{s}\right] \Delta T_{c}+\left(\dot{w}_{m d}+\dot{w}_{l}\right) \Delta T_{d}} \quad[p . u .](5.64)
$$




\section{REFERENCES}

Brealy, R., and $\mathrm{S}$. Myers. 1981. Principles of Corporate Finance. McGrawitill, New York, New York.

Commerce Clearing House. 1987. 1987 U.S. Master Tax Guide. Chicago, Mllinois.

Consolidated Capital Comonications Group. 1985. The Financial Desk Book. Emeryville, California.

CSA Energy Consultants. 1986. Electric Rate Book, Arlington, VIrginia.

Edison Electric Institute, 1986. Statistical Yearbook of the Electric Utility Industry/1985. Washington, D.C.

Electric Power Research Institute. 1982. Technical Assessment Guide. Palo Alto, California.

Energy and Environmental Analysis, Inc. 1983, Industrial Energy Productivity Project Final Report. Prepared for the U.S. Departinent of Energy, Washington, D. $\tilde{L}_{\text {. }}$

Energy Information Administration. 1987. Annual Energy Outlook 1986. washington, D.C.

Ibbotson Associates. 1987. Stocks, Bonds, Bills, and Inflation 1987 Yearbook: Market Results for 1926 - 1986. Chicago, IITnois.

Lewellen, W. G., M. S. Long, and J.J. McConnell. 1976. "Asset Leasing in Competitive Capital Markets." The Journal of Finance. June, 1976, pp. $787-798$.

Money. 1987. "Investor's Scorecard." September, 1987, pp. 27-28, 30.

Petri, R. J, et al. 1986, "High Temperature Thermal Energy Storage (TES) Systems for Industrial Applications." Presented at the 21 st Intersociety Energy Conversion Engineering Conference, San Diego, California, August 25-29, 1986.

Schall, L. 1972. "Asset Valuation, Fiml Investment, and Fim Diversification." Journal of Business. January, 1972, pp. 11-28.

U.S. Department of Commerce. Jamuary, 1987. Survey of Current Business. Washington, D.C.

U.S. Department of the Treasury. 1971. Asset Depreciation Range (ADR) Susten. Washington, D.C. 

APPENDIX A

GLOSSARY OF ECONOMIC AND PERFORMANCE TERMS 
APPENDIX A

\section{GLOSSARY OF ECONOMIC AND PERFORMANCE TERMS}

ADR (asset depreciation range) class life. Approximate ranges of useful equipment life established by the Internal Revenue Service for tax purposes.

Availability. The useful energy (i.e., energy that can be converted to work) per unit mass of a substance.

Capital Investment. In general, the expenditure of money for goods or services that will be consumed over a period of several years. Specifically, expenditures that must be depreciated for tax purposes.

Cash flow (or cash flow stream). The receipt or expenditure of cash related to a project. Examples include initial capital, operation and maintenance expenses, and revenues.

Cost account. A division of a cost reporting structure. Cost accounts are used to distinguish the boundaries between different types of costs and facilitate the communication of cost data from one user to another.

Depreciable life. The legal capital cost recovery period established by the Accelerated Cost Recovery System (ACRS). ACRS lives are generally less than ADR class lives.

Depreciation. A method of spreading the cost of capital investments over a period of several years for the purpose of calculating taxes.

Discounted payback period. The length of time required for the cumulative present value of after-tax cash flows of a project to become positive.

Discounting. The process of adjusting cash flows occurring at different times to a single reference point to compensate for the time value of money. Economic (or project) life. The number of operating years in which future cash flows are projected for use in the project economic analysis. 
Escalation. A decrease in the purchasing power of a monetary unit (e.g., the dollar) over time. "Escalation" is usually used to describe the change in price for a particular product or service or a group of products and/or services.

Expense, In general, the expenditure of money for goods or services that will be consumed within a period of one year. Specifically, expenditures that may be entirely deducted in the current year for tax purposes.

Figure-of-merit. An economic measurement (e.g., net present value, levelized production cost, etc.) used to compare two or more alternatives.

First Law Efficiency. The efficiency of a TES unit based on energy flows. A First Law Efficiency can be calculated for the charge phase, standby phase, discharge phase or the complete cycle ("round trip"). The Round Trip Efficiency is defined as the energy supplied to the load divided by the energy available in the source stream.

Inflation. A decrease in the purchasing power of a monetary unit fe.g., the dollar) over time. "Inflation" is usually used to describe the general change in prices for all goods and services.

Internal rate of return. The discount rate for a project that results in a net present value of zero.

Levelized (annualized) production cost. A unit cost equal to the annualized cost of production divided by the annual production rate. The annualized cost, recurring every year for the life of a project, has a present value equivalent to the present value of all project costs.

Maximum charge rate. The maximum rate that energy can be stored in a thernal storage unit.

Maximum discharge rate. The maximum rate that energy can be withdrawn from a thermal storage unit.

Net present value. The sum of all project cash flows discounted to a single point in time. 
Hominal (current) dollars. Dollars measured with the effects of inflation included.

Overnight cost. A measurement of capital investment that excludes any interest expense or escalation of costs that may occur during the construction period, as if the project had literally been built overnight.

Payback period. The length of time required for the cunulative after-tax cash flows of a project to becone positive.

Price year. The reference year for a cost estimate or cash flow. For example, a capital cost estinate might be based on 1987 dollars or some other year's dollars.

Profitability ratio. The net present value of a project divided by the present value of the initial capital investment.

Real (constant) dollars. Dollars measured with the effects of inflation excluded.

Revenue. The receipt of money or other goods and services for goods and services rendered.

Second Law Efficiency. The efficiency of a TES unit based on avallable energy flows. A Second Law Efficiency can be calculated for the charge phase, standby phase, discharge phase or the complete cycle ("round trip"). The Round Trip Efficiency is defined as the available energy supplied to the load divided by the available energy supplied by the source stream.

Time value of money. The consequence resulting from the fact that people prefer to consume goods innediately rather than at a later date. Lenders must be compensated for the time value of money for postponing their consumption.

Useful Storage factor. The fraction of the theoretical maxinum storage capacity that can actually be used for storage.

Volume Recovery Factor. The fraction of fluid injected into an aquifer that is recovered during discharge.

JI. A volume integral where the integrand is integrated throughout a volume. 
APPENDIX B

AN INTRODUCTION TO ECONOMIC PRINCIPLES 
APPENDIX B

\section{AN INTRODUCTION TO ECONOMIC PRINCIPLES}

General economic principles relating to net present value (NPV) and levelized production cost (LPC) analyses are presented in this appendix. Concepts such as the time value of money, inflation, and discounting are defined and explained in the context of the general approach to conducting NPV and LPC calculations. Finally, the appropriate use of NPV and LPC analyses for choosing between alternatives is discussed.

The purpose of an economic evaluation is to select the best investment, i.e., the investment that maximizes the wealth of the investor. An economically correct methodology for comparing alternatives must properly consider the time value of money. The time value of money results from the fact that people prefer to consume goods immediately rather than at a later date. A lender forgoes the use of loaned money until it is later repaid. Lenders require compensation (in the form of interest) for postponing their consumption.

As a result of the time value of money, expenses or revenues (cash flows) that occur at different times cannot be directly compared on a face value basis. The most comnon way to correctly interpret cash flows occurring at different times is through a present value calculation. In a present value calculation, a discount rate compensates for the time value of money. The discount rate is the minimum rate of return that an investor is willing to accept from the investment; in the case of a lender, the discount rate is equivalent to the interest rate charged on the loan. Interest (discount) rates are a function of the intrinsic productivity of capital (or how much additional capital can increase output of goods and services), the expected inflation rate, and a risk premium having to do with the variability of the cash flows. The rate of constant dollar interest is the compensation for postponing consumption when there is no inflation. The greater the uncertainty in the timing or magnitude of a cash flow (risk), the higher the real interest (or discount) rate will be. 
Inflation is another fundanental concept that has a significant impact on economic evaluations. Inflation is a decrease in the purchasing power of currency over time, and affects all the expenses and revenues associated with an investment. In periods of inflation, investors demand higher returns (higher discount rates) as compensation for postponing consumption because money received later will buy fewer goods and services than it will today.

Economic evaluations can handle inflation in one of two ways. The first approach is to include the effects of the expected inflation rate into all revenue and expense streams. This approach is called a nominal (or current) dollar method, and results in estimates of the actual face-value cash flows to occur in each year. The second method of accounting for inflation is to exclude the effects of inflation from all cash flows. This approach is called a real (or constant) dollar method, because it expresses all cash flows in dollars of constant purchasing power. Either approach to inflation will yieid a correct evaluation of energy alternatives. It is important though that al? the economĩc calculations remain consistent, i.e. either nominal or real.

The following equation illustrates a present value (PV) calculation that properly accounts for inflation. Assume that a person has $\$ 100$ to invest and is willing to accept $\$ 105$ in 1 year if there is no inflation and no risk. Thus, the present value of $\$ 1051$ year hence is $\$ 100$ and this person's discount rate for risk-free investments is $5 \%$, or

$$
P V=\$ 100=\frac{\$ 105}{1+0.05}
$$

Now, if there is also an inflation rate of 10\% expected over the year, the investor will require more than $\$ 105$ because the purchasing power of the money received in 1 year will be less than it is today. The investor will actually require $\$ 115.50$ in 1 year to be as well off as in the no inflation case. 
Both the cash flow and the discount rate must be adjusted for the inflation rate as shown below:

$$
P V=\$ 100=\frac{\$ 105 * 1.1}{(1+0.05) * 1.1} \frac{\$ 115.50}{1.115}
$$

All possible investments of the same risk will not necessarily earn the same rate of return. Deciding which investment to select can be done by calculating the net present value. The net present value is the difference between the amount of the investment and the present value of the cash flows to be received. For an investment to be attractive, the net present value must be greater than zero. For example, suppose a person has a chance to make a risky investment that is expected to return $\$ 30$ every year for 4 years. Assuming there is no inflation and the correct discount rate for the risk of this investment is $10 \%$, the net present value can be calculated as:

$$
\text { HPV }=\sum_{t=1}^{t=4} \frac{\$ 30}{(1+0.1)^{t}}-\$ 100=-\$ 4.90 \quad[\$]
$$

In this case, the investment should not be made since the NPV is negative.

Selecting investments with negative net present values decreases wealth, and selecting investments with positive net present values increases wealth. Businesses and individual investors at tenpt to maximize their wealth and select investments on this basis. Wealth maximization occurs when all positive NPV investments are chosen. When choosing between mutually exclusive investments, the alternative with the largest net present value will be the one that maximizes the wealth of the investor.

Levelized production cost analys is employs the concepts discussed above, but, because the result is given in terms of unit cost, the impact of an investment on the overall production economics of a process may be easier to understand when comparing alternatives. The economic result is the same, however. Selecting the lowest LPC fron the possible alternatives which provide 
equivalent service naximizes the wealth of the investors. Thus, when making investments, businesses and individual investors will generally select the option that yields the lowest LPC for their process, even though it may not be the option with the highest thermodynamic efficiency. There is a trade-off between cost and process efficiency. Levelized production cost calculations are able to correctly evaluate this trade off and wll determine the most economically efficient method.

A levelized production cost is simply an annualized cost divided by an annual output. The annualized cost is defined as the uniform cost over the process' Iife that has the same present value as all of the actual process costs. The general steps involved in calculating a LPC (assuming that the annual output and all process costs are known) are:

- calculate present values for all cost streams

- calculate capital and recurring cost contributions to annualized cost

- calculate annualized costs and levelized energy cost.

The annualized cost is made up of capital costs and recurring costs (expenses). Because the tax laws treat these costs differently, they must be considered separately in the LPC analysis. The present value of all recurring costs must be multiplied by a captul recovery factor (CRF) to yield a single annual cost that represents all recurring costs over the life of the plant. This single annual cost is equivalent to the loan payment where the princtple is equal to the present value of all the recurring costs. The contribution of the capital costs to the annualized cost is the product of the present value of the capital construction costs and the fixed charge rate (FCR). The FCR accounts for income taxes (including depreciation and investment tax credit effects), return on equity, interest on debt, insurance, property taxes, and other taxes.

Deciding between alternatives on the basis of capital cost, system efficiency, or any other single parameter will not necessarily yield the most economically efficient nethod or maximize the wealth of investors. The NPV or LPC approaches are two economically correct methods that can be used to appropriately choose between alternatives. 
There are two important constraints for NPV and LPC calculations. The first is that a selection between alternatives using these approaches is only appropriate when the alternatives are providing equivalent service. For example, two alternative cooling systems must provide the same level of comfort in their application for a comparison based on NPV or LPC to be equitable. Another concern would be the consideration of possible safety or environmental differences, which are often difficult to quantify in economic terms. Additional decision criteria would have to be used to incorporate these factors. The second constraint is that NPV or LPC comparisons are only appropriate when the economic assumptions used in the calculations are consistent. This constraint is especially important when comparing NPV or LPC calculations from different sources. The economic assumptions will substantially affect the magnitude of the NPV or LPC calculated, even though they may not alter a relative comparison of concepts. Using the NPV or LPC to compare technologies must be restricted to cases where the economic assumptions are equivalent. 


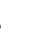


APPENDIX C

THE DEDUCTIBILITY OF INTEREST DURING CONSTRUCTION 
APPENDIX C

\section{THE DEDUCTIBILITY OF INTEREST DURING CONSTRUCTION}

Interest-related cash flows are implicitly modeled in TEAM through the use of an after-tax weighted cost of capital. This approach assumes that debt and equity fractions, rates of return, and tax rates remain constant through the life of the project (hence, the after-tax cost of capital remains constant through the life of the project) and that interest expenses are deductible in the period incurred. This latter assumption is no longer valid in certain circumstances. Specifically, regulations set forth in the 1986 Tax Reform Act (TRA) no longer allow full deductibility of interest during construction during the period incurred when the following conditions apply:

- the ADR class life of the investment is greater than or equal to 20 years, or

- the construction period is greater than 2 years, or

- the construction period is greater than 1 year, and the construction cost is greater than one million dollars.

If these conditions are satified, only $10 \%$ of the interest expense may be deducted in the year it is incurred, with the remaining $90 \%$ deducted at the rate of $10 \%$ per year over a 9-year period, beginning with the year after the year in which the interest was paid or accrued or, if later, the first year of operation.

The qualitative impact of this change in the tax laws is that the cost of borrowing (hence the cost of doing business) has increased. The present value of tax-related benefits associated with the deductibility of interest expenses has been lowered because the receipt of these benefits has been delayed by several years. The remainder of this appendix documents the equations used for calculating this increased cost to the project while maintaining the use of the after-tax weighted cost of capital. The equations define the actual amount of debt and actual amount of interest expense that would be incurred 
during each year of construction. The net increased cost to the project is equal to the present value of tax-related benefits generated by deducting interest during construction according to the schedule outlined in the TRA minus the present value of tax-related benefits generated by deducting interest during construction during the periad incurred.

To determine the amount of interest during construction for each period, the amount of debt in each period must first be determined. The complexity of this problem arises from the requirenent that the fraction of the present value of capital investment that is debt and equity must be kept constant in any given period while paying different rates of return on debt and equity.

Because the debt fraction (Debtf) and equity fraction (Equityf) must remain constant during every year of the project, additions to total debt and total equity must be made such that this condition is satisified. Thus, the following two equations must be true:

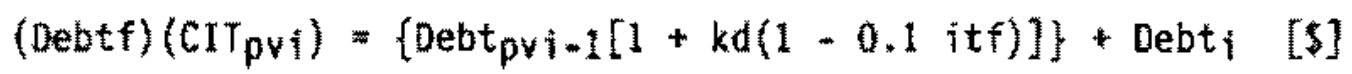

where Debtf $=$ the fraction of CITpri that is debt $=0$ DebtpvilcITpvi

CITpvi = the present value of total capital investment in year $i$

Debt $t_{\text {pyi-1 }}=$ the present value of debt in year $i-1$

$k d=$ the rate of return on debt

itf = the combined state and federal incone tax rate

Debt $i=$ the debt portion of a capital investment made in year $i$

$$
\text { (Equityf) }(\text { CITpyi) }=[\text { Equitypyi-1 }(1+\text { ke) }]+\text { Equityi }
$$

where Equityf = the fraction of CITpvi that is equity = Equity pri $_{\text {i }} / \mathrm{CIT}_{\mathrm{pvi}}$

$$
\mathrm{CIT}_{\text {pvi }} \text { = defined in Equation (C.1) }
$$

Equity $_{p v i-1}=$ the present value of equity in year $i-1$

$k e=$ the rate of return on equity

Equity $i=$ the equity portion of a captial investment made in year $i$ 
Additionally, because all funds for the capital investment are assumed to come from debt and equity financing:

$$
\operatorname{CIT}_{\mathbf{i}}=\text { Debt }_{\mathbf{j}}+\text { Equity }_{\mathbf{i}}
$$

where CIT $j$ equals the total capital investment in year $i$ and Debt $j$ and Equity $i$ were defined in Equations (C.1) and (C.2).

Solving these equations for Debt ${ }_{j}$ results in:

$$
\operatorname{Debt}_{i}=\frac{\left(A+\frac{B}{C}\right)}{D}
$$

where $A=-D e b t p v i-1[1+k d(1-0.1$ itf $)]$

$$
\begin{aligned}
& B=\text { Debtf }\left[\text { Equitypvi-1 }(1+k e)+\text { CIT }_{i}\right] \\
& C=\text { Equityf } \\
& D=\frac{1+\text { Debtf }}{\text { Equityf }}
\end{aligned}
$$

and each of the variables were defined in Equations (C.1), (C.2), and (C.3). Debtpvi-1 is the present value of debt in year $i-1$, and is related to Debt $t_{p v i}$, the present value of debt in year $i$, by the following relationship.

$$
\text { Debt }_{p v i}=\text { Debt }_{i}+\operatorname{Debt}_{p v i-1}[1+k d(1-0.1 i t f)]
$$

where Debt $i, k d$, and itf were defined in Equation (C.1).

Equitypvi-1 is the present value of equity in year $i-1$ and is related to Equity ${ }_{\text {pvi }}$, the present value of equity in year $i$, by the following relationship.

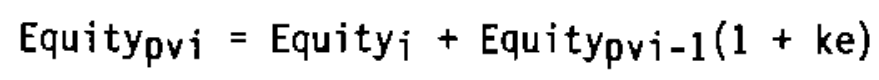


where Equityi, Equity ${ }_{\text {pyill, }}$, and ke were defined in Equation (C.2). Finally, CIT $p$ is is related to CIT; by the following relationship.

$$
\text { CITpri }=\operatorname{CITi}+\operatorname{CIT} i-1(1+k)
$$

where CIT pri and CITi were defined in Equations $(C .1)$ and $(C .3), C I T_{i-1}$ is the total capital investment in year $i-1$, and $k$ is the after-tax overall discount rate.

The actual interest expense incurred in each period is equal to the present value of debt in the previous year multiplied by the debt rate, as shown in Equation (C.8).

$$
\operatorname{Int} i=\text { Debtpri-1 }^{*} k d
$$

where Int $i$ is the interest expense incurred in year $i$, and Debtpvi-i and $k d$ are defined above.

Under the tax laws prior to the TRA, the interest expense during each period also represented the anount of interest deducted from taxable income each period. Under the laws specified in the TRA, only $10 \%$ of the interest expense incurred during construction is deducted in the period incurred.

$$
\text { Intded } i_{2}<1=0.1 * \text { Int } i
$$

where Int dedi, $<1$ is the interest expense deductible in year $i$ for interest expense incurred in year $i$ and int $f$ is defined above.

One-tenth of the cumulative interest incurred during the years priar to the year the facility is placed in service (the last year of construction) is deducted during the year the facility is place in service and in the subsequent 8 years.

$$
\text { Intdedi, } i=0,8=0.1 * \sum_{i} \text { Inti, } i<0
$$


where Int ded $i, i=0,8$ is the annual interest deductions allowed in years 0 through 8 for interest expenses incurred prior to the last year of construction and Int $_{i}$ is defined above.

One-tenth of the interest expense incurred during the year the facility is placed in service (the last year of construction) is deducted in the year following the year the facility is placed in service and in the subsequent 8 years.

$$
\text { Int ded } i, i=1,9=0.1 * \text { Int }_{i, i=0}
$$

where Int $t_{\text {ded }} i, i=1,9$ is the annual interest deductions allowed in years 1 through 9 for interest expenses incurred during the last year of construction and Int $_{j}$ is defined above.

Hence, the yearly deductions for interest during construction are as follows:

- During all years of construction prior to the last year of construction, Equation (C.9) applies.

- In the last year of construction, the deduction is equal to the sum of Equations (C.9) and (C.10).

- In years 1 through 8, the deduction is equal to the sum of Equations (C.10) and (C.11).

- During year 9, the deduction is given by Equation (C.11).

In general, the present value of interest expenses and the present value of income taxes generated by interest expenses are calculated as for any other operation and maintenance expense. The present value of interest expenses occurring in year $i$ is calculated as:

$$
\text { Int }_{p v i}=\frac{\text { Int }_{\text {dedi }}}{\left(1+\text { Int }_{k}\right)^{i}}
$$

where Intpvi is the present value of interest expenses deductible in year $i$, Intdedi is the sum of all deductible interest expenses in year $i$, and Int $_{k}$ is the discount rate for interest expenses. 
The total present value of interest expenses (Int $p v$ ) is equal to the summation over all $i$ of Intpri. The present value of the income taxes generated by int (Intpvt) is calculated as:

$$
\operatorname{Int} t_{p y t}=-\operatorname{In} t_{p v} \text { * itf }
$$

where Intprt is the present value of income taxes generated by interest expenses, Intpv is the present value of all interest expenses, and itf is defined above.

The negative sign indicates that interest expenses represent income tax savings. 
APPENDIX D

MULTIPLE DISCOUNT RATE ANALYSIS 
APPENoYX 0

\section{MULTIPLE DISCOUNT RATE ANALYSIS}

Section 3.3 .3 introduced the concept of employing unique discount rates for individual cash flow streans.

As schall (1972) has demonstrated in his "value additivity principle," the value of the total [cash flow] stream must, in a transactioncostless competitive capital narket, be equal to the sum of the respective values of individual [cash flow] components.... [Such that] $k_{1}, \ldots, k_{1}$ are capitalization (discount) rates commensurate with the risk features of the separate elements, in the light of investor opportunities to trade in sinilar such [cash flow] streams elsewhere in the market (Lewellen 1976).

Therefore, each individual cash flow strean in project could be discounted at a different rate. This would generally be done only when the project being considered is of a different market risk than the nomal investment that the company makes. An investment in TES equipment could be such an investment.

Market risk is deternined by how changes in a project's cash flows "covary" with the market returns. Beta is the measure of the market risk of a cash flow stream. This cash flow stream could be for the total company, an individual project, or the cash flows associated with a particular part of project (e.g., operating and maintenance cost). For a cash flow stream $x_{\text {, beta }}$ is defined as:

$$
f_{x}=\frac{\operatorname{cov}(x, m k t)}{[s t d(m k t)]^{2}}
$$

where cov $(x, m k t)$ is the covariance of the changes in the cash flow strean $x$ and the return on the market portfolio, and std (mkt) is the standard deviation of the retum on the market portfolio. 
Because the covariance is equal to:

$$
\operatorname{cov}(x, m k t)=\operatorname{corr}(x, m k t)+\operatorname{std}(x)+\operatorname{std}(m k t) \quad[p . u .](0.2)
$$

where corr $(x$, nkt) $)$ is the correlation of the changes in the cash flow stream $x$ and the return on the market portfolio, and std $(x)$ is the standard deviation of the percentage changes in cash flow stream $x$.

Beta can also be defined as:

$$
\beta_{x}=\frac{\operatorname{corr}(x, m k t) * \operatorname{std}(x)}{s t d(n k t)}
$$

Thus, to calculate the beta of a cash flow stream directly, each term in Equation (0.3) nust be known. The standard deviation of the return on the market portfolio can be assuned to be the sane as it was in the past and this value is easily calculated from the Ibbotson data on market returns (Ibbotson Associat 1986). The two terms in the numerator are much more difficult to calculate/estimate, In fact, in many cases it may not be possible at all.

However, the problem can be bounded. If a cash flow does not vary at all from its expected value then the standard deviation is zero and the beta is zero. A zero beta will also occur if the changes in a cash flow strean have zero correlation with the return on the market. In both cases, using Equation (3.1), the correct discount rate is easily calculated to be equal to the riskfrese rate.

In other cases there is some data available as to the nature of the cash flow strean. For example, for energy prices and labor rates, historical data are available. However, to use them one nust assume that the quantities of energy and labor to be used will be the same in each period. If this is the case, then the historical data could be used to provide a good estimate of the future variability of the cash flow and its correlation with the returns on the market portfolio. Because the changes in energy and labor prices are not well correlated with the returns on the market (and, in fact, are often negatively correlated). the estimated beta and, hence, the discount rate would be very low. 
The implication for evaluations of TES equipment or other energy conservation measures is significant. Lowering the discount rate applied to projections of future energy cost savings increases the estimated present value of these savings and, hence, improves the general economic viability of the energy saving equipment. Because the impact of employing individual cash flow discount rates could be very beneficial to TES system economics, follow-on work to clarify and quantify the impact is strongly recommended. 


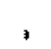

. 
APPENDIX E

AVAILABILITY 
APPENDIX E

\section{AVAILABILITY}

The concept of availability(a) is a powerful way of evaluating themal systems because availability indicates the quality of energy in addition to the quantity. As an example, in the definition of First Law Round Trip Efficiency, the denominator consists of $Q_{s}+W_{s}+W_{a c}+W_{a d}+W_{k}$. The heating represented by $Q_{5}$ is probably at a relatively low temperature llet"s assume $200^{\circ} \mathrm{Cl}$. One $\mathrm{kJ}$ of energy at this temperature could not be completely converted to work. Instead, if it is assumed that Qs can be converted to work in a Carnot cycle and reject heat to a heat sink with a temperature of $0^{\circ} \mathrm{c}$, the heat engine would only produce $0.57 \mathrm{~kJ}$ of work for each $\mathrm{kJ}$ of heat supplied by $\mathrm{q}_{\mathrm{s}}$. Clearly the low-temperature heat is not as valuable as the work indicated in $W_{5}$. Wac, Wad, and we and it is nisleading to combine these in a single quantity. This is the fundamental problem with using first Law Efficiency alone as a themodynanic figure-of-merit.

To get around this problem, we can define a property called "availability". This property is the maximum anount of work that can be extracted from a source, given the ambient conditions. As an example, assume that $Q_{s}$ is the thermal energy in $1 \mathrm{~kg}$ of water at $100^{\circ} \mathrm{C}$ and 1 atm pressure. The maximum anount of work that can be extracted from Qs results from the water being cooled to ambient temperature by a heat engine, where the heat engine is producing work. When the temperature of the water equals the surrounding temperature, no addi tional work can be extracted. The total extracted work is the "availability" of the water in reference to its surroundings.

In general, it can be shown that the avallability in any fiutd in the absence of kinetic and potential energy changes is:

$$
f=\left(u-u_{0}\right)+P_{0}\left(v-v_{0}\right)-T_{0}\left(s-s_{0}\right)
$$

(a) Currently there is no standard terminology for second law analysis, availability is also referred to as exergy or essergy. 
where $\phi=$ availability $(\mathrm{kJ} / \mathrm{kg})$

$\mathrm{u}=$ internal energy $(\mathrm{kJ} / \mathrm{kg})$

$P_{0}=$ ambient pressure $(\mathrm{kPa})$

$v=$ specific volume $\left(\mathrm{m}^{3} / \mathrm{kg}\right)$

$T_{0}=$ ambient temperature $(K)$

$\mathrm{s}=$ entropy $(\mathrm{kJ} / \mathrm{kg}-\mathrm{K})$

Subscripts

$0=$ property evaluated at ambient conditions

In addition, availability can be expressed in terms of enthalpy. Enthalpy is a measure of a system's energy, but it does not include any measure of the quality of the energy. Availability considers the quality of the energy. Enthalpy is defined by Equation (E.2).

$$
h=u+P v
$$

Substituting Equation (E.2) into Equation (E.1) yields Equation (E.3) describing the maximum work that can be extracted from a thermodynamic system in the absence of changes in kinetic and potential energy.

$$
\phi=\left(h-h_{0}\right)-T_{0}\left(s-s_{0}\right)
$$

Equation (E.3) shows that availability is the difference between the enthalpy of the system at its pressure and temperature and the enthalpy of the system evaluated at ambient conditions with consideration of entropy effects.

Now that we can determine the "availability", we can accurately combine heat flows (such as $Q_{s}$ ) and work flows. We do this by determining the availability of the heat flows. Because a work flow consists only of work, its availability always equals its energy. The use of availability results in the Second Law Efficiency. For our example, Qs would be replaced by $m_{s}\left(\phi_{s h}-\phi_{s l}\right)$ where the $\phi_{s h}-\phi_{s l}$ is the change in availability per $\mathrm{kg}$ of source fluid. 


\section{DISTRIBUTION}

No. of

Copies

OFFSITE

U.S. Department of Energy

Attn: K. Klein

Office of Energy Storage oist.

Forresta1 Bldg, CE-141 5E-052

Washington, DC 20585

U.S. Department of Energy

Attn: E. Reiners

Office of Energy Storage Dist.

Forrestal B1dg, CE-141 5E $\% 052$

Washington, DC 20585
DoE Technical Information
Center

Argonne National Laboratory Solar Themal Storage Program Attn: A. Gorsky

Duliding 362

9700 S. Cass Avenue

Argonne, IL 60439

Lawrence Berkeley Laboratory

Attn: M. Wahlig

University of california

Bldg. $90-2024$

1 Cyclotron Road

Berkeley, CA 94720

New York State Energy

Research \& Development Agency

Attn: Director

Rockefeller plaza

Albany, NY 12223
No. of

copies

New York State Energy

Research : Development Agency

Attn: G. Walmet

Rockefeller Plaza

Albany, NY 12223

Oak Ridge National Laboratory

Attn: M. Taylor

PO Box $X$

Oak Ridge, TN 37830

Oak Ridge National Laboratory

Attn: J. Tomlinson

PO Box $X$

Oak Ridge, TN 37830

Office of Congressman

sid Morrison

Attn: Kevin Billings.

Legislative Asst.

1330 Longworth Bldg.

Washington, DC 20515

Solar Energy Research Institute

Attn: B. Gupta

1536 cole Blud

Golden, Co 80401

University of Alabama

Attn: E. Brett

School of Hines and Energy Development.

Box 6282

University, AL 35486

University of Alabama

Attn: W. Schaetzle

School of Mines and Energy Development

Box 6282

University, AL 35486 
No. of

Copies

US Department of Interior

Attn: Natural Resources

Library

Serials Branch (6)

Washington, DC 20240

\section{FOREIGN}

Bengt Hidemark Gosta Danielson Arkitekter SAR

Attn: A. Boysen

Jarntorget 78

S-11 29 Stockholm

Sweden

Comission of European

Communities

Attin: P. Zegers

DG $\times 11, E 3$

200 Veststraat

Brussels, Belgium

Heidemij Adviesbureau

Attn: A. Snijders

P0 Box 254

NL-6800 AG Arnhen

The Netherlands

I.E.N.E.R.

EPF-Ecublens

Aten: B. Saugy

1015 Lausanne

Switzerland

KFA Julich

Projektleitung Energieforschung

Attn: F.J. Friedrich

PO Box 1913

[-5170 Julich

West Germany
$\mathrm{No}+$ of

Copies

KFA Julich, PLE
Attn: V. Lottner
PO Box 1913
D-5170 Julich
West Germany

Laboratory for Energetics

Attn: B. Qyale

Technical University of Denmark DK-2800 Lyngby

Denmark

Management office for Energy Research PEO

Atto: K. Joon

P. 0. Box 8242

NL-Utrecht

The Netherlands

B. Mathey

Consulting-Engineers Ltd.

2205 Monezillon-Neuchatel

Switzerland

Public Works of Canada

Attn: E. L. Marofsky

C456 Sir Charles Tupper Bldg.

Riverside Dr. and Heron Rd.

ottawa, Ontario

KIA OM2 Canada

Riso National Laboratory

Attn: P. L. Christensen

ok-4000 Roskilde

Denmark

Swedish Council for Building

Research

Attn: $S-E$. Lundin

St. Goransgatan 66

$5-11233$ Stockholm

Sweden 
No. of

Copies

Swedish Council for Building Rosearch

Attn: W. Raldow

St, Goransgatan 66

\$-112 33 stockholm

Sweden

Swiss Federal Energy Office

Attn: A, Fehr

$\mathrm{CH}=3003$ Berne

Switzerland
No. of

Copies

ONSITE

DoE Richland Operations Office

J. J. Sutey

35 Pacific Northwest Laboratory

R. C. Adams

J. M. Bates

0. R. Brown (10)

J. A. Dirks

M. K. Drost

C. H. Imhoff

L. O. Kannberg (10)

G. E. Spanner

R. O. Weijo

T. A. Willians

Technical Report Files (5)

Publishing Coordination (2) 
